International Debt Deleveraging 
The Working Paper series of the Oesterreichische Nationalbank is designed to disseminate and to provide a platform for discussion of either work of the staff of the OeNB economists or outside contributors on topics which are of special interest to the OeNB. To ensure the high quality of their content, the contributions are subjected to an international refereeing process. The opinions are strictly those of the authors and do in no way commit the OeNB.

The Working Papers are also available on our website (http://www.oenb.at) and they are indexed in RePEc (http://repec.org/).

Publisher and editor

Editorial Board

of the Working Papers

\section{Coordinating editor}

Design
Oesterreichische Nationalbank

Otto-Wagner-Platz 3, 1090 Vienna, Austria

PO Box 61, 1011 Vienna, Austria

www.oenb.at

oenb.info@oenb.at

Phone (+43-1) 40420-6666

Fax (+43-1) 40420-046698

Doris Ritzberger-Grünwald, Ernest Gnan, Martin Summer

Martin Summer

Communications and Publications Division

\section{DVR 0031577}

(C) Oesterreichische Nationalbank, 2013. All rights reserved. 


\section{Editorial}

On the occasion of the 65th birthday of Governor Klaus Liebscher and in recognition of his commitment to Austria's participation in European monetary union and to the cause of European integration, the Oesterreichische Nationalbank (OeNB) established a "Klaus Liebscher Award". It has been be offered annually since 2005 for up to two excellent scientific papers on European monetary union and European integration issues. The authors must be less than 35 years old and be citizens from EU member or EU candidate countries. Each "Klaus Liebscher Award" is worth EUR 10,000. The winning papers of the ninth Award 2013 were written by Luca Fornaro and by Jenny Simon and Justin Valasek (shared award). Luca Fornaro's paper is presented in this Working Paper while Jenny Simon's and Justion Valasek's contribution is contained in Working Paper 183.

In this paper Luca Fornaro provides a framework for understanding debt deleveraging in a group of financially integrated countries. During an episode of international deleveraging world consumption demand is depressed and the world interest rate is low, reflecting a high propensity to save. If exchange rates are allowed to float, deleveraging countries can depreciate their nominal exchange rate to increase production and mitigate the fall in consumption associated with debt reduction. The key insight of the paper is that in a monetary union this channel of adjustment is shut off, and therefore the falls in consumption demand and in the world interest rate are amplified. Hence, monetary unions are especially prone to hit the zero lower bound on the nominal interest rate and enter a liquidity trap during deleveraging. In a liquidity trap deleveraging gives rise to a union-wide recession, which is particularly severe in high-debt countries. The model suggests several policy interventions that mitigate the negative impact of deleveraging on output in monetary unions.

June 10, 2013 



\title{
International Debt Deleveraging
}

\author{
Luca Fornaro*
}

November 2012

\begin{abstract}
I provide a framework for understanding debt deleveraging in a group of financially integrated countries. During an episode of international deleveraging world consumption demand is depressed and the world interest rate is low, reflecting a high propensity to save. If exchange rates are allowed to float, deleveraging countries can depreciate their nominal exchange rate to increase production and mitigate the fall in consumption associated with debt reduction. The key insight of the paper is that in a monetary union this channel of adjustment is shut off, and therefore the falls in consumption demand and in the world interest rate are amplified. Hence, monetary unions are especially prone to hit the zero lower bound on the nominal interest rate and enter a liquidity trap during deleveraging. In a liquidity trap deleveraging gives rise to a union-wide recession, which is particularly severe in high-debt countries. The model suggests several policy interventions that mitigate the negative impact of deleveraging on output in monetary unions.
\end{abstract}

\section{JEL Classification Numbers: E31, E44, E52, F32, F34, F41, G01, G15.}

\author{
Keywords: Global Debt Deleveraging, Liquidity Trap, Monetary Union, Pre- \\ cautionary Savings, Debt Deflation.
}

\footnotetext{
*Department of Economics, London School of Economics, Houghton Street, WC2A 2AE London. E-mail: l.fornaro@lse.ac.uk. Website: personal.lse.ac.uk/fornaro. I am extremely grateful to Gianluca Benigno, Christopher Pissarides and Romain Ranciere for encouragement and invaluable suggestions. For useful comments, I thank Nathan Converse, Wouter den Haan, Ethan Ilzetzki, Robert Kollmann, Pascal Michaillat, Michele Piffer, Kevin Sheedy and Silvana Tenreyro. I also thank seminar participants at the LSE, University of Montreal, Federal Reserve Bank of Boston, Columbia University, Federal Reserve Bank of New York, University of Maryland, CREI, IIES, ECB, Banca d'Italia, Brown University, University of Wisconsin Madison and Bank of England, and participants at the 2012 meeting of the Society for Economic Dynamics, the 2012 EEA meeting, the conference on International Capital Flows and Spillovers in a Post-Crisis World at the Bank of England, the 2013 RES conference and the 8th Annual Workshop of the CEPR Working Group on Macroeconomics of Global Interdependence at the University of Lausanne. I gratefully acknowledge financial support from the French Ministère de l'Enseignement Supérieur et de la Recherche, the ESRC, the Royal Economic Society and the Paul Woolley Centre.
} 


\section{Introduction}

Episodes of global debt deleveraging are rare, but when they occur they come with deep recessions and destabilize the international monetary system. In the Great Depression of the 1930s the world entered a period of global debt reduction and experienced the most severe recession in modern history. The cornerstone of the international monetary system, the Gold Standard, came under stress and was abandoned in 1936, when the remaining countries belonging to the Gold Block gave up their exchange rate pegs against gold. Almost 80 years later, history seems to be repeating itself. Following the 2007-2008 turmoil in financial markets several advanced economies started a process of private debt deleveraging accompanied by a deep economic downturn, the Great Recession. Once again, the status quo in the international monetary system is challenged, and this time the survival of the Eurozone is called into question. These events might suggest that fixed exchange arrangements, such as monetary unions, are hard to maintain during times of global debt deleveraging, but more research is needed to understand exactly why this chain of events is set in motion during deleveraging episodes.

My objective in this paper is to develop a framework for the study of the implications of debt deleveraging in a group of financially integrated countries. During an episode of international deleveraging world demand for consumption is depressed and the world interest rate is low, reflecting a high propensity to save. If exchange rates are allowed to float, deleveraging countries can rely on a depreciation to increase production and mitigate the fall in consumption associated with debt reduction. The key insight of the paper is that in a monetary union this channel of adjustment is shut off, because high-debt countries cannot depreciate against the other countries in the monetary union, and therefore the falls in the demand for consumption and in the interest rate are amplified. Hence, during an episode of deleveraging monetary unions are especially prone to hit the zero lower bound on the nominal interest rate and enter a liquidity trap. In a liquidity trap standard monetary policy tools are ineffective and deleveraging gives rise to a deflationary recession. This effect contributes to explain why episodes of debt deleveraging are particularly painful for monetary unions.

The model features a continuum of small open economies trading with each other. Each economy is inhabited by households which borrow and lend to smooth the impact of temporary, country-specific, productivity shocks on consumption, in the spirit of the Bewley (1977) closed economy model. Foreign borrowing and lending arise endogenously as households use the international credit market to insure against country-specific productivity shocks.

Each household is subject to an exogenous borrowing limit. I study an episode of deleveraging triggered by a tightening of the borrowing limit, which I call a deleveraging shock. To 
isolate the role of the exchange rate regime in shaping the response to a deleveraging shock I compare the adjustment under two different versions of the model. I start by considering a model without nominal rigidities. I then analyze the case of a monetary union with nominal wage rigidities.

In both versions of the model, the process of debt reduction generates a fall in the world interest rate, which overshoots its long run value. This is due to two different effects. On the one hand, the countries starting with a relatively high stock of debt are forced to reduce it by the tightening of the borrowing limit. On the other hand, the countries starting with a low stock of debt, as well as those starting with a positive stock of foreign assets, want to increase precautionary savings as a buffer against the risk of hitting the borrowing limit in the future. Both effects lower consumption demand and generate a rise in the propensity to save. As a result, the world interest rate must fall to guarantee that the rest of the world absorbs the forced savings of high-debt borrowing-constrained economies.

In a world without nominal rigidities the deleveraging process also entails a rise in production in high-debt economies. Households can repay their debts not only by cutting consumption, but also by working more to increase their labor income. Thus, households living in high-debt countries increase their labor supply in response to the deleveraging shock. If wages are flexible, this generates a drop in real wages and a rise in employment and output in high-debt countries.

A large body of evidence, reviewed below, suggests that nominal wages adjust slowly to shocks. In particular nominal wages do not fall much during deep recessions, in spite of sharp rises in unemployment. With nominal wage rigidities I show that nominal exchange rate flexibility can substitute for nominal wage flexibility. But in a monetary union exchange rates between members are fixed and the adjustment in real wages cannot be achieved through movements in the nominal exchange rate. I focus on this case in the main part of the paper.

The combination of nominal wage rigidities and fixed exchange rates prevents any increase in employment and production in high-debt economies in response to the deleveraging shock. Households living in the high-debt countries of the monetary union have to reduce their debt solely by decreasing consumption. The deep fall in consumption demand coming from highdebt countries amplifies the increase in the propensity to save and the fall in the world interest rate during deleveraging. Because of this effect, the chances that an episode of deleveraging gives rise to a liquidity trap are particularly high for monetary unions.

When the central bank of the monetary union is constrained by the zero lower bound on the nominal interest rate, deleveraging gives rise to a deflationary union-wide recession. Because 
the interest rate cannot fall enough to guarantee market clearing, firms decrease prices in order to eliminate excess supply. Given the sticky nominal wages, the fall in prices translates into a rise in real wages that reduces employment and production. Moreover, if debt is denominated in nominal terms deflation causes a redistribution of wealth from debtor to creditor countries that further reduces consumption demand and production. ${ }^{1}$ The recession hits high-debt countries particularly hard, but the economic downturn also spreads to the countries that are not financially constrained, because the common interest rate and trade linkages tie all the countries of the union together.

Finally, I discuss policy interventions that mitigate the recession during deleveraging in monetary unions. First, I show that if the central bank of the monetary union has a higher inflation target the fall in output during deleveraging is smaller. When the nominal interest rate hits the zero bound the real interest rate is equal to the inverse of expected inflation, and so a higher inflation target implies a lower real interest rate, which stimulates consumption demand and production. Second, I consider a policy that slows down the tightening of the borrowing constraint, giving more time to agents to adjust to the new credit conditions. This policy dampens the rise in the propensity to save during the early phases of the deleveraging episode, stimulating consumption and limiting the drop in output.

This paper is related to several strands of the literature. First, the paper is about liquidity traps. Early works studying liquidity traps in micro-founded models, such as Krugman (1998), Eggertsson and Woodford (2003) and Svensson (2003), were motivated by the weak economic performance of Japan during the 1990s, occurring in the context of low inflation and nominal interest rates stuck at zero. The precipitous fall in policy rates experienced by advanced economies during the current crisis has renewed the interest in liquidity traps. ${ }^{2}$ While traditionally the literature has relied on preference shocks to generate liquidity traps, recently a few contributions have drawn the connection between deleveraging and drops in the interest rate. Guerrieri and Lorenzoni (2011) and Eggertsson and Krugman (2012) study the impact of deleveraging shocks on the interest rate in closed economies, while Pierpaolo Benigno and Romei (2012) consider deleveraging in a two-country model. My paper contributes to this literature by demonstrating that monetary unions are more likely to enter a liquidity trap during deleveraging.

A key feature of the model I propose is the presence of nominal wage rigidities. There is extensive evidence in support of the existence of nominal wage rigidities, both at the macro

\footnotetext{
${ }^{1}$ This is the debt-deflation effect emphasized by Fisher (1933) in the context of the Great Depression.

${ }^{2}$ See Robert Hall's presidential address at the 2011 AEA meeting (Hall, 2011). See also Jeanne (2009) and Cook and Devereux (2011), who use a two-country model to study a global liquidity trap.
} 
and at the micro level. From a macro perspective, there is evidence that wage contracts are set on average once a year in OECD countries. This observation has been used by Olivei and Tenreyro $(2007,2010)$ to show empirically that nominal wage rigidities play a key role in transmitting monetary policy shocks to the real economy. ${ }^{3}$ There is also evidence suggesting that nominal wages adjust slowly to changes in prices and unemployment during deep recessions. In their empirical studies, Eichengreen and Sachs (1985) and Bernanke and Carey (1996) find that nominal wage rigidities contributed substantially to the fall in output during the Great Depression, in particular among countries belonging to the Gold Block. ${ }^{4}$ More recently, Schmitt-Grohé and Uribe (2011) have documented the importance of nominal wage rigidities in the context of the 2001 Argentine crisis and of the Great Recession in countries at the Eurozone periphery. ${ }^{5}$ Another strand of the literature shows the relevance of nominal wage rigidities using micro data. For example, Fehr and Goette (2005), Gottschalk (2005) and Barattieri et al. (2010) use worker-level data to show that changes in nominal wages, especially downward, happen infrequently. Fabiani et al. (2010) obtain similar results using firm-level data from several European countries.

The paper also relates to the literature studying precautionary savings in incomplete-market economies with idiosyncratic shocks. The literature includes the seminal works of Bewley (1977), Deaton (1991), Huggett (1993), Aiyagari (1994) and Carroll (1997), who consider closed economies in which consumers borrow and lend to self-insure against idiosyncratic income shocks. ${ }^{6}$ Guerrieri and Lorenzoni (2011) use a Bewley model to study the impact of deleveraging on the interest rate in a closed economy. My paper shares with their work the focus on precautionary savings. Starting from Clarida (1990), some authors have used multi-country models with idiosyncratic shocks and incomplete markets to study international capital flows. Examples are Castro (2005), Bai and Zhang (2010) and Chang et al. (2009). This is the first paper that employs a multi-country Bewley model to study the interactions between deleveraging, the exchange rate regime and liquidity traps.

\footnotetext{
${ }^{3} \mathrm{~A}$ similar conclusion is reached by Christiano et al. (2005) using an estimated medium scale DSGE model of the US economy.

${ }^{4}$ The importance of nominal wage rigidities in the US during the Great Depression is discussed in more detail in Bordo et al. (2000).

${ }^{5}$ In addition, several authors, including Shimer (2010), Hall (2011) and Midrigan and Philippon (2011), have emphasized the key role of real wage rigidities in rationalizing the 2008-2009 recession following the turmoil in financial markets. More broadly, Michaillat (2012) shows that real wage rigidities are important in explaining unemployment during recessions in the US. In this paper real wage rigidities arise from the combination of nominal wage rigidities and fixed exchange rates.

${ }^{6}$ There is also a literature relating precautionary savings and the business cycle. The classic contribution is Krusell and Smith (1998), while recent works are Guerrieri and Lorenzoni (2012) and Challe and Ragot (2012). Rather than focusing on business cycles, this paper considers the response of precautionary savings to a large financial shock.
} 
The current events in the Eurozone have revived the literature on the macroeconomic management of monetary unions. Recent contributions build on the multi-country framework developed by Gali and Monacelli (2008). ${ }^{7}$ Their framework abstracts from financial frictions, a key element in my analysis. Another recent work that relates to the Eurozone crisis is Schmitt-Grohé and Uribe (2011). The authors highlight how the combination of downward nominal wage rigidities in the non-tradable sector and fixed exchange rates can generate involuntary unemployment and recessions in small open economies. Their focus is on a single small open economy that takes the world interest rate as given, while in my paper the endogenous determination of the world interest rate is crucial.

From an empirical perspective, this paper is linked to the work of Lane and Milesi-Ferretti (2012), who look at the adjustment in the current account balances during the Great Recession. They find that the compression in the current account deficits was larger for those countries that were relying more heavily on external financing before the crisis. Moreover, they find that most of the adjustment passed through a compression in domestic demand, contributing to the severity of the crisis in deficit countries. My model rationalizes these facts. ${ }^{8}$

This paper also speaks to the empirical findings of Mian et al. (2011) and Mian and Sufi (2012). These authors find that the fall in consumption and employment in the US during the 2008-2009 recession was stronger in those counties where the pre-crisis expansion in credit driven by the rise in house prices was more pronounced. This evidence is consistent with the results of my paper, if the monetary union version of the model is interpreted as a large country composed of many different regions. Midrigan and Philippon (2011) also address this evidence using an approach complementary to mine. They look at a cash-in-advance model in which credit can be used as a substitute for fiat money. In their model, the fall in consumption is generated by a decrease in the provision of private credit that tightens households' cashin-advance constraints, while here the emphasis is on intertemporal debt and liquidity traps. Another empirical work that relates to this paper is Nakamura and Steinsson (2011). Their results on fiscal stimulus across US states lend support to models of monetary unions in which aggregate demand has an impact on production.

The rest of the paper is structured as follows. Section 2 introduces the model and briefly analyzes the steady state. Section 3 considers the adjustment following a deleveraging shock in a world with flexible wages. Section 4 shows that the depressive impact of deleveraging on the

\footnotetext{
${ }^{7}$ Examples are Werning and Farhi (2012), who look at the optimal management of fiscal policy in a monetary union, and Farhi et al. (2011), who derive a set of fiscal measures able to substitute for exchange rate flexibility inside a currency union. Instead, Pierpaolo Benigno (2004) uses a two-country model to study monetary unions.

${ }^{8}$ The paper is also related to the empirical literature on the rise of precautionary savings during the Great Recession. See Carroll et al. (2012) and Mody et al. (2012).
} 
interest rate is stronger in a monetary union with nominal wage rigidities. Section 5 describes the role of the zero lower bound in translating a deleveraging episode into a recession. Section 6 introduces a version of the model parameterized at quarterly frequency and performs policy experiments. Section 7 concludes.

\section{Model}

Consider a world composed of a continuum of measure one of small open economies. Each economy can be thought of as a country. ${ }^{9}$ Time is discrete and indexed by $t$. Each country is populated by a continuum of measure one of identical infinitely lived households and by a large number of firms. All economies produce two consumption goods: a homogeneous tradable good and a non-tradable good. Countries face idiosyncratic shocks in their production technologies, while the world economy has no aggregate uncertainty. Households borrow and lend on the international credit markets in order to smooth the impact of productivity shocks on consumption. There is an exogenous limit on how much each household can borrow. I start by analyzing the steady state of the model, in which the borrowing limit is held constant. The next section studies the transition after an unexpected shock that tightens the borrowing limit.

Households. Households derive utility from the consumption of a tradable good $C^{T}$ and of a non-tradable good $C^{N}$ and experience disutility from labor effort $L$. The expected lifetime utility of the representative household in a generic country $i$ is

$$
E_{0}\left[\sum_{t=0}^{\infty} \beta^{t} U\left(C_{i, t}^{T}, C_{i, t}^{N}, L_{i, t}\right)\right] .
$$

In this expression, $E_{t}[\cdot]$ is the expectation operator conditional on information available at time $t$ and $\beta$ is the subjective discount factor. The period utility function $U(\cdot)$ is assumed to be increasing in the first two arguments, decreasing in the third argument, strictly concave and twice continuously differentiable.

Each household can trade in one period risk-free bonds. Bonds are denominated in units of the tradable consumption good and pay the gross interest rate $R_{t}$. The interest rate is common across countries and can be interpreted as the world interest rate.

There are no trade frictions and the price of the tradable good is the same in every country. Normalizing the price of the traded good to 1 , the household budget constraint expressed in

\footnotetext{
${ }^{9}$ Another possibility is to think of an economy as a region inside a large country, for example a US state or county.
} 
units of the tradable good is

$$
C_{i, t}^{T}+p_{i, t}^{N} C_{i, t}^{N}+\frac{B_{i, t+1}}{R_{t}}=w_{i, t} L_{i, t}+B_{i, t}+\Pi_{i, t}^{T}+\Pi_{i, t}^{N}
$$

The left-hand side of this expression represents the household's expenditure. $p_{i}^{N}$ denotes the price of a unit of non-tradable good in terms of the tradable good in country $i{ }^{10}$ Hence, the term $C_{i}^{T}+p_{i}^{N} C_{i}^{N}$ is the total expenditure of the household in consumption expressed in units of the tradable good. $B_{i, t+1}$ denotes the purchase of bonds made by the household at time $t$ at price $1 / R_{t}$. If $B_{i, t+1}<0$ the household is a borrower.

The right-hand side captures the household's income. $w_{i} L_{i}$ is the household's labor income. Labor is immobile across countries and hence the wage $w_{i}$ is country-specific. $B_{i, t}$ is the gross return on investment in bonds made at time $t-1$. Finally, $\Pi_{i}^{T}$ and $\Pi_{i}^{N}$ are the profits received from firms operating respectively in the tradable and in the non-tradable sector. All domestic firms are wholly owned by domestic households and equity holdings within these firms are evenly divided among them.

There is a limit on how much each household is able to borrow. In particular, debt repayment cannot exceed the exogenous limit $\kappa$, so that the bond position has to satisfy ${ }^{11}$

$$
B_{i, t+1} \geq-\kappa
$$

This constraint captures in a simple form a case in which a household cannot credibly commit in period $t$ to repay more than $\kappa$ units of the tradable good to its creditors in period $t+1{ }^{12}$

The household's optimization problem is to choose $C_{i, t}^{T}, C_{i, t}^{N}, L_{i, t}$ and $B_{i, t+1}$ to maximize the expected present discounted value of utility (1), subject to the budget constraint (2) and the borrowing limit (3), taking the initial bond holdings $B_{i, 0}$ and prices $R_{t}, p_{i, t}^{N}, w_{i, t}$ as given. The household's first-order conditions can be written as

$$
\begin{gathered}
p_{i, t}^{N}=\frac{U_{C_{i, t}^{N}}}{U_{C_{i, t}^{T}}} \\
-U_{L_{i, t}}=w_{i, t} U_{C_{i, t}^{T}}
\end{gathered}
$$

\footnotetext{
${ }^{10} p_{i}^{N}$ is not necessarily equalized across countries because the non-traded good is, by definition, not traded internationally.

${ }^{11}$ Throughout the analysis I assume that the exogenous borrowing limit $\kappa$ is tighter than the natural borrowing limit.

${ }^{12}$ In reality tight access to credit may manifest itself through high interest rates, rather than through a quantity restriction on borrowing. In appendix B I show that it is possible to recast the borrowing limit (3) in terms of positive spreads over the world interest rate without changing any of the results.
} 


$$
\begin{gathered}
\frac{U_{C_{i, t}^{T}}}{R_{t}}=\beta E_{t}\left[U_{C_{i, t+1}^{T}}\right]+\mu_{i, t} \\
B_{i, t+1} \geq-\kappa, \quad \text { with equality if } \mu_{i, t}>0,
\end{gathered}
$$

where $U_{x}$ denotes the first derivative of the utility function with respect to $x$ and $\mu_{i}$ is the nonnegative Lagrange multiplier associated with the borrowing limit. The optimality condition (4) equates the marginal rate of substitution of the two consumption goods, tradables and non-tradables, to their relative price. Equation (5) is the optimality condition for labor supply. Equation (6) is the Euler equation for bonds. The binding borrowing constraint generates a wedge between the marginal utility from consuming in the present and the marginal utility from consuming next period, given by the shadow price of relaxing the borrowing constraint $\mu_{i}$. Finally, equation (7) is the complementary slackness condition associated with the borrowing limit.

Firms. Firms rent labor from households and produce both consumption goods, taking prices as given. A typical firm in the tradable sector in country $i$ maximizes profits

$$
\Pi_{i, t}^{T}=Y_{i, t}^{T}-w_{i, t} L_{i, t}^{T}
$$

where $Y_{i}^{T}$ is the output of tradable good and $L_{i}^{T}$ is the amount of labor employed by the firm. The production function is

$$
Y_{i, t}^{T}=A_{i, t}^{T}\left(L_{i, t}^{T}\right)^{\alpha_{T}}
$$

where $0<\alpha_{T}<1 .^{13} A_{i}^{T}$ is a productivity shock affecting all firms in the tradable sector in country $i$. This is the source of idiosyncratic uncertainty that gives rise to cross-country financial flows in steady state. Profit maximization implies

$$
\alpha_{T} A_{i, t}^{T}\left(L_{i, t}^{T}\right)^{\alpha_{T}-1}=w_{i, t}
$$

This expression says that at the optimum firms equalize the marginal profit from an increase in labor, the left-hand side of the expression, to the marginal cost, the right-hand side.

Similarly, firms in the non-tradable sector maximize profits

$$
\Pi_{i, t}^{N}=p_{i, t}^{N} Y_{i, t}^{N}-w_{i, t} L_{i, t}^{N}
$$

where $Y_{i}^{N}$ is the output of non-tradable good and $L_{i}^{N}$ is the amount of labor employed in

\footnotetext{
${ }^{13}$ To introduce constant returns-to-scale in production we can assume a production function of the form $Y_{i, t}^{T}=A_{i, t}^{T}\left(L_{i, t}^{T}\right)^{\alpha_{T}} K^{1-\alpha_{T}}$, where $K$ is a fixed production factor owned by the firm, for example physical or organizational capital. The production function in the main text corresponds to the normalization $K=1$.
} 
the non-tradable sector. Labor is perfectly mobile across sectors within a country and hence firms in both sectors pay the same wage $w_{i}$. The production function available to firms in the non-tradable sector is

$$
Y_{i, t}^{N}=A^{N}\left(L_{i, t}^{N}\right)^{\alpha_{N}}
$$

where $0<\alpha_{N}<1$. The term $A^{N}$ determines the productivity of firms in the non-tradable sector. To reduce the number of state variables and save on computation costs, I assume that $A^{N}$ is constant and common across all countries. ${ }^{14}$ The optimal choice of labor in the non-tradable sector implies

$$
p_{i, t}^{N} \alpha_{N} A_{i, t}^{N}\left(L_{i, t}^{N}\right)^{\alpha_{N}-1}=w_{i, t}
$$

Just as firms in the tradable sector, at the optimum firms in the non-tradable sector equalize the marginal benefit from increasing employment to its marginal cost. ${ }^{15}$

Market clearing. Since households inside a country are identical, we can interpret equilibrium quantities as either household or country specific. For instance, the end-of-period net foreign asset position of country $i$ is equal to the end-of-period holdings of bonds of the representative household divided by the world interest rate ${ }^{16}$

$$
N F A_{i, t}=\frac{B_{i, t+1}}{R_{t}}
$$

Market clearing for the non-tradable consumption good requires that in every country consumption is equal to production, that is $C_{i, t}^{N}=Y_{i, t}^{N}$. Moreover, equilibrium on the labor market implies that in every country the labor supplied by the households is equal to the labor demanded by firms, $L_{i, t}=L_{i, t}^{T}+L_{i, t}^{N}$.

These two market clearing conditions, in conjunction with the budget constraint of the household and the expressions for firms' profits, give the market clearing condition for the tradable consumption good in country $i$

$$
C_{i, t}^{T}=Y_{i, t}^{T}+B_{i, t}-\frac{B_{i, t+1}}{R_{t}}
$$

This expression can be rearranged to obtain the law of motion for the stock of net foreign

\footnotetext{
${ }^{14}$ Empirically, productivity in the non-tradable sectors is much less volatile than in the tradable sectors. For example, see Stockman and Tesar (1995).

${ }^{15}$ Throughout the paper I focus on equilibria in which production always occurs in both sectors. Given the functional forms used in the numerical simulations, it is indeed optimal for firms to always operate in both sectors.

${ }^{16}$ I follow the convention of netting interest payments out of the net foreign asset position.
} 
assets owned by country $i$, i.e. the current account

$$
N F A_{i, t}-N F A_{i, t-1}=C A_{i, t}=Y_{i, t}^{T}-C_{i, t}^{T}+B_{i, t}\left(1-\frac{1}{R_{t-1}}\right)
$$

As usual, the current account is given by the sum of net exports, $Y_{i, t}^{T}-C_{i, t}^{T}$, and net interest payments on the stock of net foreign assets owned by the country at the start of the period, $B_{i, t}\left(1-1 / R_{t-1}\right)$.

Finally, in every period the world consumption of the tradable good has to be equal to the world production, $\int_{0}^{1} C_{i, t}^{T} \mathrm{~d} i=\int_{0}^{1} Y_{i, t}^{T} \mathrm{~d} i$. This implies that bonds are in zero net supply at the world level, $\int_{0}^{1} B_{i, t+1} \mathrm{~d} i=0$.

\subsection{Equilibrium}

Given a sequence of prices $\left\{R_{t}, w_{i, t}, p_{i, t}^{N}\right\}_{t=0}^{\infty}$, define the optimal decisions of the household as $C^{T}\left(B, A^{T}\right), C^{N}\left(B, A^{T}\right)$ and $L\left(B, A^{T}\right)$ and the optimal labor demand decisions as $L^{T}\left(A^{T}\right)$ and $L^{N}$, in a country with bond holdings $B_{i t}=B$ and productivity $A_{i, t}^{T}=A^{T}$. Notice that these decision rules fully determine the transition for bond holdings.

Define $\Psi_{t}\left(B, A^{T}\right)$ as the joint distribution of bond holdings and current productivity across countries. The optimal decision rules for bond holdings together with the process for productivity yield a transition probability for the country-specific states $\left(B, A^{T}\right)$. This transition probability can be used to compute the next period distribution $\Psi_{t+1}\left(B, A^{T}\right)$, given the current distribution $\Psi_{t}\left(B, A^{T}\right)$. We can now define an equilibrium.

Definition 1 An equilibrium is a sequence of prices $\left\{R_{t}, w_{i, t}, p_{i, t}^{N}\right\}_{t=0}^{\infty}$, a sequence of policy rules $C^{T}\left(B, A^{T}\right), C^{N}\left(B, A^{T}\right), L\left(B, A^{T}\right), L^{T}\left(A^{T}\right), L^{N}$ and a sequence of joint distributions for bond holdings and productivity $\Psi_{t}\left(B, A^{T}\right)$, such that given the initial distribution $\Psi_{0}\left(B, A^{T}\right)$ in every period $t$

- $C^{T}\left(B, A^{T}\right), C^{N}\left(B, A^{T}\right), L\left(B, A^{T}\right), L^{T}\left(A^{T}\right), L^{N}$ are optimal given $\left\{R_{t}, w_{i t}, p_{i t}^{N}\right\}_{t=0}^{\infty}$

- $\Psi_{t}\left(B, A^{T}\right)$ is consistent with the decision rules

- Markets for consumption and labor clear in every country $i$

$$
\begin{gathered}
C_{i, t}^{N}=Y_{i, t}^{N} \\
C_{i, t}^{T}=Y_{i, t}^{T}+B_{i, t}-\frac{B_{i, t+1}}{R_{t}}
\end{gathered}
$$


Table 1: Parameters

\begin{tabular}{lll}
\hline & Value & Source/Target \\
\hline Risk aversion & $\gamma=4$ & Standard value \\
Discount factor & $\beta=0.9756$ & $R=1.025$ \\
Frisch elasticity of labor supply & $1 / \psi=1$ & Kimball and Shapiro $(2008)$ \\
Labor share in tradable sector & $\alpha_{T}=0.65$ & Standard value \\
Labor share in non-tradable sector & $\alpha_{N}=0.65$ & Standard value \\
Share of tradables in consumption & $\omega=0.5$ & Stockman and Tesar (1995) \\
TFP process & $\sigma_{A^{T}}=0.0194, \rho=0.84$ & Benigno and Thoenissen $(2008)$ \\
Initial borrowing limit & $\kappa=0.9$ & World debt/GDP $=20 \%$ \\
\hline
\end{tabular}

$$
L_{i, t}=L_{i, t}^{T}+L_{i, t}^{N}
$$

- The market for bonds clears at the world level

$$
\int_{0}^{1} B_{i, t+1} \mathrm{~d} i=0
$$

\section{$2.2 \quad$ Parameters}

The model cannot be solved analytically and I analyze its properties using numerical simulations. I employ a global solution method in order to deal with the nonlinearities involved by a large shock such as the deleveraging shock studied in the next section. Appendix A describes the numerical solution method.

I assume a utility function separable in consumption and labor and a Cobb-Douglas aggregator for consumption

$$
\begin{gathered}
U\left(C^{T}, C^{N}, L\right)=\frac{C^{1-\gamma}}{1-\gamma}-\frac{L^{1+\psi}}{1+\psi} \\
C=\left(C^{T}\right)^{\omega}\left(C^{N}\right)^{1-\omega} .
\end{gathered}
$$

A period in the model corresponds to one year. ${ }^{17}$ The risk aversion is set to $\gamma=4$, a standard value. The discount factor is set to $\beta=0.9756$ in order to match a real interest rate in the initial steady state of 2.5 percent. This is meant to capture the low interest rate environment characterizing the US and the Euro area in the years preceding the start of the 2007 crisis. The Frisch elasticity of labor supply $1 / \psi$ is set equal to 1 , in line with evidence by Kimball and Shapiro (2008). The labor share in production in both sectors is set to $\alpha_{T}=\alpha_{N}=0.65$, a value in the range of those commonly used in the literature. The share of tradable goods in consumption is set to $\omega=0.5$, in accordance with the estimates of Stockman and Tesar (1995).

Productivity in the tradable sector $A^{T}$ follows a normal $\operatorname{AR}(1)$ process $A_{i, t}^{T}=\rho A_{i, t-1}^{T}+\epsilon_{i, t}$.

\footnotetext{
${ }^{17}$ Later, in section 6 , I will parametrize the model at quarterly frequency to perform policy experiments.
} 
Current account

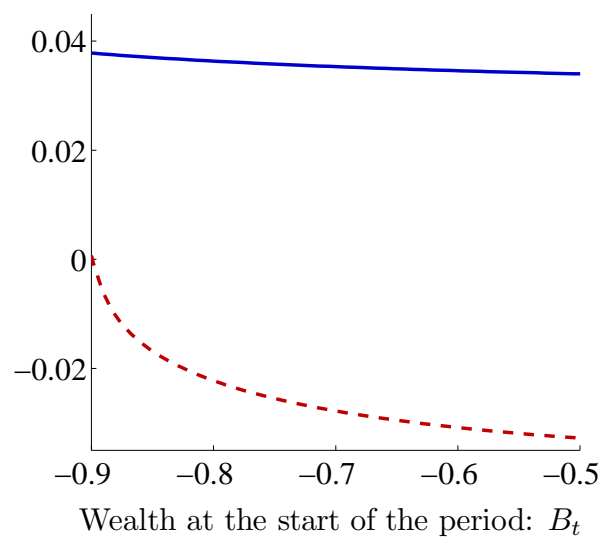

Labor

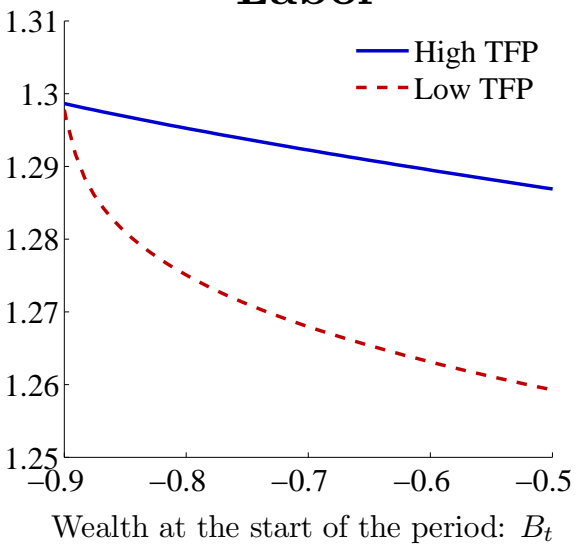

Figure 1: Policy functions in steady state.

This process is approximated with the quadrature procedure of Tauchen and Hussey (1991) using 7 nodes. ${ }^{18}$ The first order autocorrelation $\rho$ and the standard deviation of the TFP process $\sigma_{A^{T}}$ are set respectively to 0.84 and to 0.0194 , following the estimates of Gianluca Benigno and Thoenissen (2008). ${ }^{19}$

The borrowing limit in the initial steady state is set to $\kappa=0.9$ to match a world gross debt-to-GDP ratio of 20 percent. This target corresponds to the sum of the net external debt position of the Euro area debtor countries in 2007, expressed as a fraction of the Euro area GDP. $^{20}$

\subsection{Steady state}

Before proceeding with the analysis of the deleveraging episode, this section briefly describes the steady state policy functions and the stationary distribution of the net foreign asset-to-GDP ratio.

Figure 1 displays the optimal choices for the current account and labor as a function of $B_{t}$, the stock of wealth at the start of the period, for an economy hit by a good productivity shock, solid lines, and by a bad productivity shock, dashed lines. ${ }^{21}$ The left panel shows the current account. As it is standard in models in which the current account is used to smooth consumption over time, a country runs a current account surplus and accumulates foreign assets when

\footnotetext{
${ }^{18}$ I use the weighting function proposed by Flodén (2008), which delivers a better approximation to highpersistence $\mathrm{AR}(1)$ processes than the weighting function originally suggested by Tauchen and Hussey (1991).

${ }^{19}$ These values are in the range of those commonly used in the literature on international risk sharing. See, for example, Corsetti et al. (2008).

${ }^{20}$ The Euro area countries that have a negative net foreign asset position in 2007 are Austria, Finland, Greece, Ireland, Italy, Netherlands, Portugal and Spain. Data are from Lane and Milesi-Ferretti (2007).

${ }^{21}$ Precisely, the high (low) TFP lines refer to economies hit by a productivity shock about two standard deviations above (below) the mean.
} 


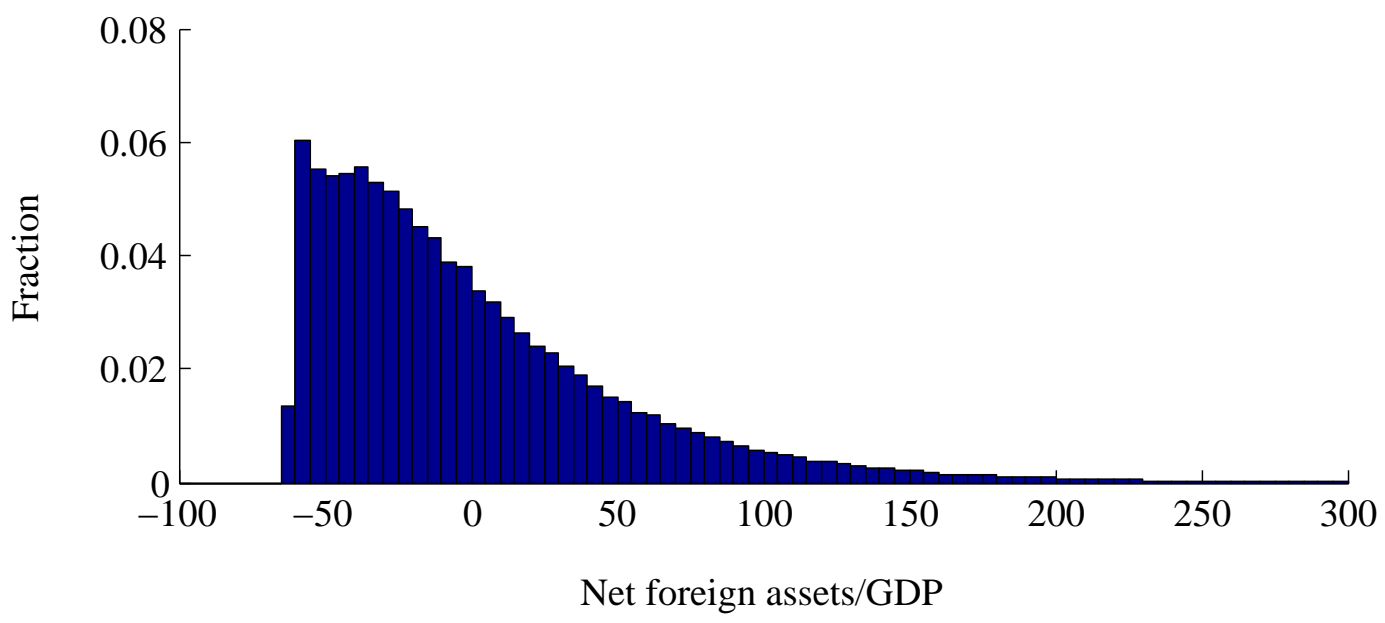

Figure 2: Steady state distribution of net foreign assets/GDP.

productivity is high, while it runs a current account deficit and reduces its stock of foreign assets when productivity is low. This allows households to mitigate the impact of temporary productivity shocks on consumption. However, the borrowing limit interferes with consumption smoothing. To see this point, notice that the decrease in net foreign assets following a bad productivity shock gets smaller as the start-of-period wealth falls. This happens because households, as they approach the constraint, reduce the accumulation of debt in response to bad productivity shocks for fear of ending up against the borrowing limit. ${ }^{22}$

The right panel illustrates the optimal choice of labor. In general, equilibrium labor is higher when productivity is high. Intuitively, when productivity is higher firms are able to pay higher wages and this induces households to supply more labor. However, as the start-of-period wealth decreases the distance between the two lines tends to fade away. In fact, households that start the period with a high stock of debt are willing to work more for a given wage, since the borrowing limit interferes with their ability to further accumulate debt in order to smooth the impact of productivity shocks on consumption.

Figure 2 shows the steady state distribution of the net foreign asset-to-GDP ratio. The distribution is truncated and skewed toward the left. Both of these features are due to the borrowing limit. In fact, while there is no limit to the positive stock of net foreign assets that a country can accumulate, the borrowing constraint imposes a bound on the negative net foreign asset position that a country can reach. In particular, the largest net foreign debt position-to-GDP ratio that a country can reach in the initial steady state is close to 65 percent.

\footnotetext{
${ }^{22}$ Indeed, when the borrowing limit is hit the country can no longer use the current account to smooth consumption and the change in net foreign assets following a bad productivity shock is equal to zero.
} 


\section{Borrowing limit}
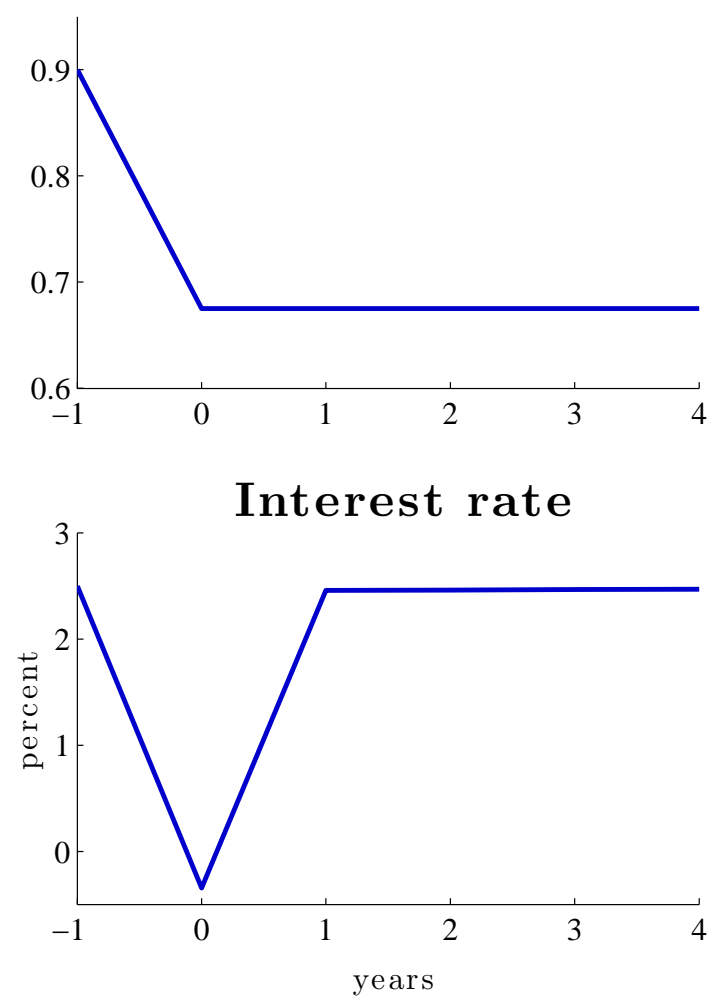
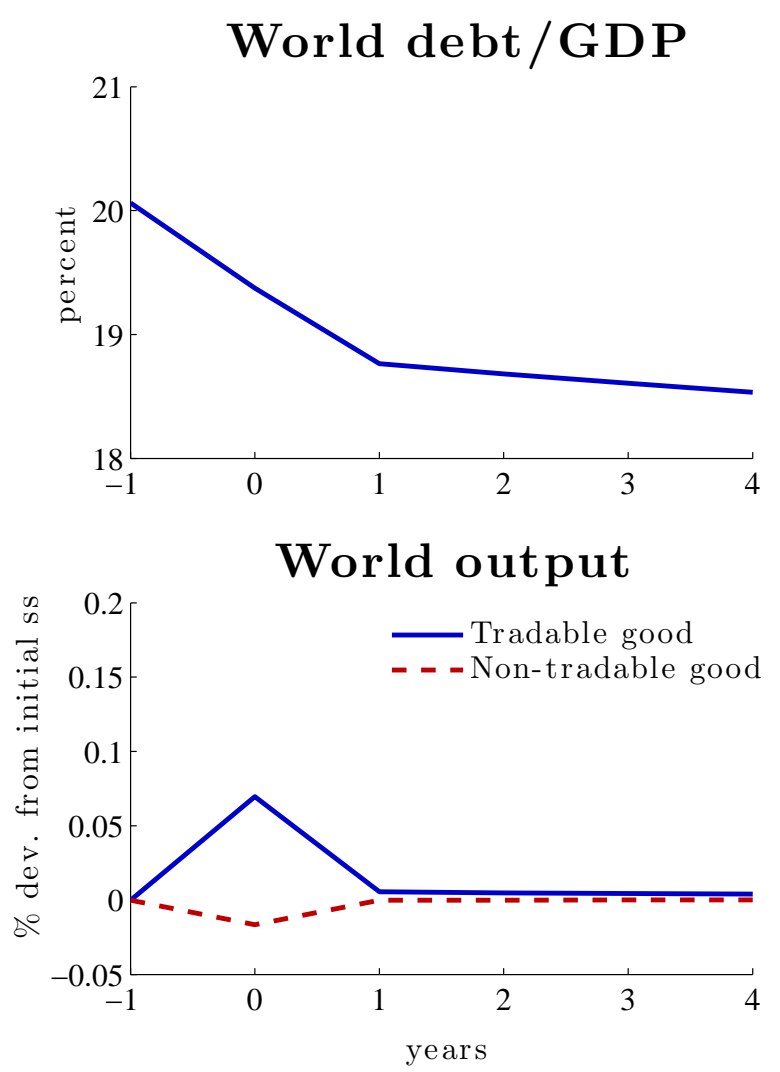

Figure 3: Response to deleveraging shock - flexible wages.

\section{Deleveraging with flexible wages}

This section analyzes the transition during a deleveraging episode induced by a tightening of the borrowing limit. I consider a world economy that starts in steady state with $\kappa=0.9$. In period $t=0$ there is an unexpected and permanent fall in the borrowing limit which goes to $\kappa^{\prime}=0.675$, so that the new borrowing limit is equal to 75 percent of the initial one. ${ }^{23}$ This generates a reduction in the steady state world gross debt-to-GDP ratio of about 5 percent. ${ }^{24}$

Figure 3 displays the transitional dynamics of the world economy following the shock to the borrowing limit. The figure shows the path for the exogenous borrowing limit and the response of the world gross debt-to-GDP ratio, the world interest rate and the world production of tradable and non-tradable goods.

The tightening of the borrowing limit triggers a decrease in the foreign debt position of highly indebted countries. At the same time, surplus countries are forced to reduce their

\footnotetext{
${ }^{23}$ For simplicity, I consider an exogenous drop in the borrowing limit. See Perri and Quadrini (2011) for a model in which changes in the borrowing limit are the result of self-fulfilling expectations.

${ }^{24}$ This number is not an unreasonable estimate of the adjustment that the Eurozone may undergo during the next years. For instance, the deviation from a linear trend, computed using data for the period $1980-2007$, of the net external debt position of the Euro area debtor countries in 2007, expressed as a fraction of the Euro area GDP, is close to 5 percentage points. This suggests that the ratio of the net external debt position of Eurozone debtor countries to Euro area GDP should fall by 5 percent in order to go back to trend.
} 
positive net foreign asset position, which is the counterpart of foreign debt in indebted countries. The result is a progressive compression of the net foreign asset distribution. As showed by the the top right panel of figure 3, on impact the world debt-to-GDP ratio falls by almost 1 percent. Afterward, the world slowly transits toward the new steady state debt distribution, in which the world debt-to-GDP ratio is equal to 15 percent.

The world interest rate drops sharply after the shock and overshoots its value in the new steady state. This result is reminiscent of the findings of Guerrieri and Lorenzoni (2011) in closed economies. The fall in the interest rate signals an increase in the desire to save, or equivalently a fall in the desire to consume. This is due to two distinct effects. First, countries that start with a high level of foreign debt, more precisely countries that start with a stock of bonds $-\kappa \leq B_{i, 0}<-\kappa^{\prime}$, are forced to reduce their foreign debt position. This corresponds to a forced increase in savings that depresses the demand for consumption in high-debt countries. ${ }^{25}$ Second, even the countries that are not directly affected by the tightening of the constraint experience an increase in the propensity to save. In fact, unconstrained countries want to accumulate precautionary savings to self-insure against the risk of hitting the now-tighter borrowing limit in the future, following a sequence of bad realizations of the productivity shock. Both these effects imply an increase in the propensity to save at the world level. In order to reach equilibrium on the bond market the interest rate has to fall, so as to induce the unconstrained countries to consume more and reduce their demand for saving instruments. This explains the fall in the world interest rate.

Concerning output, there is not much action going on at the world level. On impact, the world output of the tradable good increases by little more than 0.05 percentage points above its value in the initial steady state, while there is an almost imperceptible fall in the world output of non-tradable goods. However, the lack of aggregate movements in world output masks important country-level composition effects, to which we turn next.

Figure 4 illustrates how the response to the deleveraging shock in period $t=0$ varies across the initial distribution of net foreign assets. ${ }^{26}$ The figure shows the response, that is the change with respect to the initial steady state value, of the current account-to-GDP ratio, the output of the traded good and the consumption of the traded good. To ease interpretation the figure also displays the position of the $20^{t h}$ and the $50^{t h}$ percentile of the bond distribution. ${ }^{27}$ The

\footnotetext{
${ }^{25}$ This effect is also present in Eggertsson and Krugman (2012) and in Pierpaolo Benigno and Romei (2012).

${ }^{26}$ To construct this figure, I first computed the response in period $t=0$ to the deleveraging shock for every possible realization of the state variables $\left\{A_{0}^{T}, B_{0}\right\}$. Then I computed an aggregate response as a function of $B_{0}$ by taking the weighted average of the single country responses. The weights are given by the fraction of countries having a given realization of $A_{0}^{T}$ conditional on $B_{0}$.

${ }^{27}$ To improve readability, the figure is truncated at the $90^{\text {th }}$ percentile of the bond distribution.
} 

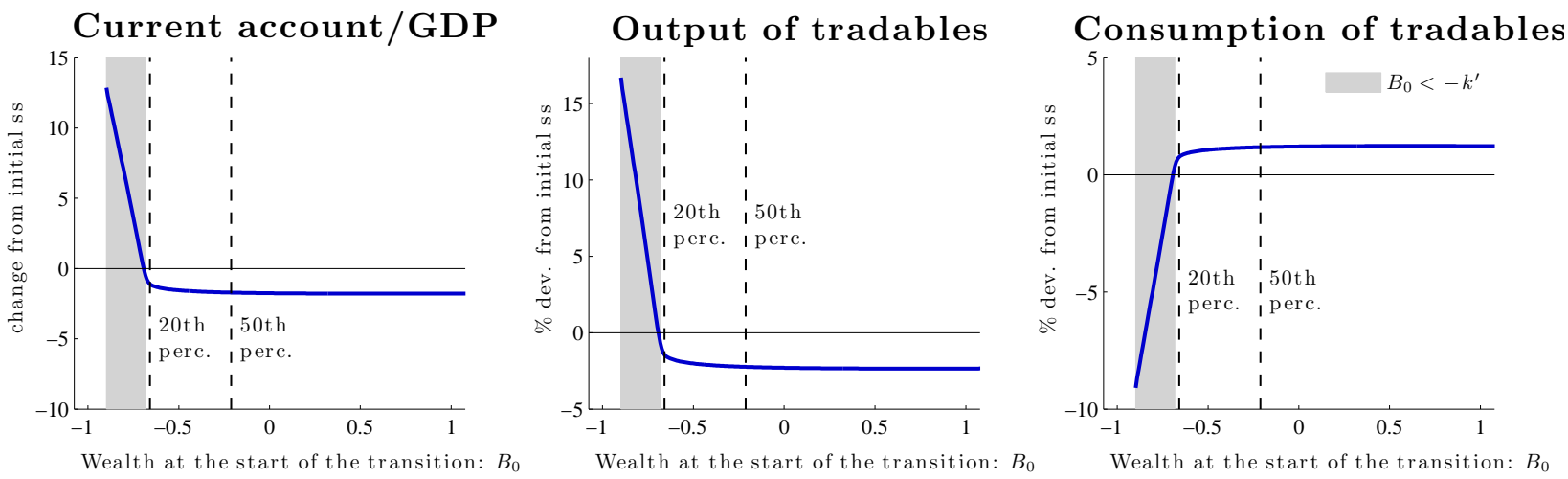

Figure 4: Impact responses to deleveraging shock across the NFA distribution - flexible wages.

shaded areas denote the countries that start the transition with $B_{i, 0}<-\kappa^{\prime}$ and hence are forced to improve their bond position by the tightening of the constraint. They represent roughly 20 percent of the countries in the world.

The figure indicates that the sign of the response to the deleveraging shock essentially depends on whether the country is forced to reduce its stock of debt by the tightening of the constraint or not. This happens because constrained countries are directly affected by the tightening of the constraint, while the response of the rest of the world is mainly dictated by the fall in the interest rate.

The left panel of figure 4 shows that the tightening of the constraint forces high-debt countries to improve their foreign asset position by increasing their current account balances. To understand the macroeconomic implications, it is useful to go back to the equation describing the current account

$$
C A_{i, t}=Y_{i, t}^{T}-C_{i, t}^{T}+B_{i, t}\left(1-\frac{1}{R_{t-1}}\right)
$$

This expression makes clear that an economy can improve its current account by increasing its output of the tradable good, by decreasing the consumption of the tradable good or through a combination of both. The middle and right panels of figure 4 show that constrained countries adjust both through the output and the consumption margin. ${ }^{28}$ Hence, in the absence of nominal rigidities, a decrease in capital inflows due to a tightening of the borrowing constraint has an expansionary impact on the production of the traded good in high-debt countries. ${ }^{29}$ Later, we will see that the combination of nominal wage rigidities and fixed exchange rates overturns this counterfactual implication of the model.

The countries that are not directly affected by the tightening of the constraint follow an opposite adjustment pattern. The sharp decrease in the world interest rate induces the uncon-

\footnotetext{
${ }^{28}$ Quantitatively, the increase in production of the tradable good dominates the fall in consumption.

${ }^{29}$ See Chari et al. (2005) for a discussion of this feature of the frictionless neoclassical model.
} 
strained countries to reduce their stock of foreign assets by running current account deficits. The deficits in the current account are achieved trough a combination of lower production of the tradable good and higher consumption. Hence, following a deleveraging shock the model without nominal rigidities displays a shift of production of tradable goods from wealthy countries toward high-debt countries. ${ }^{30}$

The response of output to the shock to the borrowing limit is associated with changes in real wages. To see this point, it is useful to rearrange the optimality condition for firms in the tradable sector to obtain

$$
L_{i, t}^{T}=\left(\frac{\alpha_{T} A_{i, t}}{w_{i, t}}\right)^{\frac{1}{1-\alpha_{T}}} .
$$

This expression implies that, given values for the parameters $\alpha_{T}$ and $A_{i, t}^{T}$, an increase in employment in the tradable sector in country $i$ has to come with a decrease in the real wage $w_{i, t} \cdot{ }^{31}$

Following the deleveraging shock, households in high-debt countries increase labor supply to boost labor income and to repay debts without cutting consumption too severely. The increase in labor supply translates into a fall in real wages, which represent the cost of labor in terms of the tradable consumption good. In turn, the fall in real wages makes more profitable for firms in the tradable sector to employ labor. This effect leads to an increase in employment and output in the tradable sector in high-debt economies. Hence, the fall in real wages in high-debt countries plays a key role in shaping the adjustment to the deleveraging shock.

The empirical evidence reviewed in the introduction suggests that nominal wages adjust sluggishly to shocks. In particular, a recurrent pattern in severe recessions is that nominal wages do not fall much, even in the face of large rises in unemployment. It is then difficult to imagine that the adjustment in real wages required by the deleveraging shock could come from an adjustment in nominal wages.

In a world in which exchange rates are allowed to float, nominal exchange rate flexibility may substitute for the lack of nominal wage flexibility. The intuition can be gained using a simple partial equilibrium approach. Suppose that there is an international currency in which

\footnotetext{
${ }^{30}$ The figure also highlights the importance of nonlinearities. In fact, while the response of unconstrained countries does not depend much on their initial stock of assets, the initial debt position has a strong impact on the response of constrained countries.

${ }^{31}$ More precisely, given that the production function is Cobb-Douglas we can write the elasticity of real wages with respect to employment in the tradable sector as

$$
\frac{\partial w_{i, t}}{\partial L_{i, t}^{T}} \frac{L_{i, t}^{T}}{w_{i, t}}=\alpha_{T}-1
$$

Given that $\alpha_{T}=0.65$, a one percent increase in employment in the tradable sector entails a 0.35 percent decrease in the real wage.
} 
the tradable good is priced. Let $P^{T}$ denote the price of the tradable good expressed in units of the international currency. Given the absence of trade frictions, the law of one price holds and the price of the tradable good in terms of the domestic currency is given by

$$
P_{i, t}^{T}=S_{i, t} P_{t}^{T}
$$

where $S_{i, t}$ denotes the nominal exchange rate of country $i$ 's against the key currency, i.e. the units of country $i$ currency needed to buy one unit of the key currency.

The real wage, that is the nominal wage divided by the price of the tradable good, is now given by

$$
w_{i, t}=\frac{W_{i, t}}{P_{i, t}^{T}}=\frac{W_{i, t}}{S_{i, t} P_{t}^{T}},
$$

where $W_{i, t}$ denotes the nominal wage in country $i$. This expression shows that, given $P_{t}^{T}$ and $W_{i, t}$, a reduction in the real wage can come through a nominal exchange rate depreciation against the key currency, that is an increase in $S_{i}$. It follows that to mimic the response to the deleveraging shock under flexible wages, despite the presence of nominal wage rigidities, high-debt countries should let their exchange rate depreciate against the key currency, while low-debt countries should let their nominal exchange rate appreciate. Indeed, from the point of view of a single country replicating the flexible wage equilibrium through movements in the nominal exchange rate corresponds to the optimal policy.

Proposition 1 From the perspective of a single country the flexible wage equilibrium attains the first best.

Proof. See appendix C.

Looking at the current events affecting the Euro area, many commentators have argued that the combination of rigidities in wage setting and fixed exchange rates has contributed to the severity of the crisis in deleveraging countries. ${ }^{32}$ A point that is often overlooked is that in a financially integrated world all the countries are tied together by the world interest rate, and that the exchange rate regime can have an important role in shaping the behavior of the world interest rate during an episode of global debt deleveraging. The next section introduces a model of a monetary union and shows that important insights can be gained from adopting a general equilibrium approach and taking into account the interactions across countries inside a monetary union.

\footnotetext{
${ }^{32}$ For example, see Feldstein (2010) and Krugman (2010).
} 


\section{Deleveraging in a monetary union with nominal wage rigidities}

This section focuses on the impact of deleveraging in a monetary union with nominal wage rigidities. To consider the case of a monetary union we have to modify the model introduced in the previous section in a few dimensions. In particular, the model presented in this section explicitly considers nominal, in addition to real, variables.

In a monetary union there is a single currency that is used for transactions in all the participating countries. For simplicity, I will consider a world in which every country belongs to the monetary union. From now on, I will then use the words monetary union and world interchangeably.

The household's budget constraint in units of currency is

$$
P_{t}^{T} C_{i, t}^{T}+P_{i, t}^{N} C_{i, t}^{N}+\frac{B_{i, t+1}}{R_{t}^{N}}=W_{i, t} L_{i, t}+B_{i, t}+\Pi_{i, t}^{T}+\Pi_{i, t}^{N}
$$

In this expression, $P^{T}$ denotes the price of a unit of tradable consumption good in terms of currency. Since the tradable good is homogenous and there are no trade frictions, its price is common across all the countries. $P_{i}^{N}$ is the nominal price of a unit of non-tradable consumption good, and it is country specific. Realistically, bonds are denominated in units of currency and $R^{N}$ denotes the gross nominal interest rate. $W_{i}$ is the nominal wage in country $i$. Finally, $\Pi_{i}^{T}$ and $\Pi_{i}^{N}$ are now the profits of the firms expressed in nominal terms.

For consistency with the model outlined in the previous section, I assume that the borrowing constraint limits the amount of tradable goods that a household can commit to repay during the following period. Formally, for every household the end-of-period bond position has to satisfy

$$
\frac{B_{i, t+1}}{P_{t+1}^{T}} \geq-\kappa
$$

There is a single central bank that uses the nominal interest rate $R^{N}$ as its policy instrument. I start by considering the case of a central bank that targets inflation in the tradable sector. This policy captures in a simple way the objective of stabilizing prices across all the countries in the union, usually characterizing central banks in monetary unions. Moreover, this policy allows for a clean comparison with the flexible wage economy described in the previous sections. In fact, as long as the central bank avoids unexpected movements in the price of the tradable 
good, nominal bonds and bonds denominated in units of tradables are perfect substitutes. ${ }^{33}$ To simplify the exposition, I start by focusing on a central bank that strictly targets inflation in the traded sector, and hence sets $P_{t}^{T}=P_{t-1}^{T}$ in every period $t$.

To capture the sluggish adjustment of nominal wages typical of deep recessions, while keeping the intuition underlying the main result of the paper transparent, I start by considering a very simple form of nominal wage rigidities. I assume that wages are completely rigid during the first period in which the unexpected shock to the borrowing limit hits the economy, period $t=0$, while they become fully flexible thereafter. ${ }^{34}$ Once wages are set, workers stand ready to supply the labor demanded by firms. Moreover, I assume that nominal wages in $t=0$ are set after the uncertainty about the idiosyncratic productivity shocks is resolved, but before the shock to the borrowing limit hits the economy. These assumptions about wage setting isolate the role of wage rigidities in shaping the adjustment to the deleveraging shock, abstracting from the impact of wage rigidities on normal business cycle fluctuations, captured by the idiosyncratic productivity shocks.

More precisely, the timing during period $t=0$ is the following:

1. At the start of the period countries are hit by their idiosyncratic productivity shocks.

2. Nominal wages are set so that the pattern of production characterizing the flexible wage equilibrium is replicated as long as the central bank sticks to the inflation target, that is if $P_{0}^{T}=E_{-1}\left[P_{0}^{T}\right]$.

3. The shock to the borrowing limit is revealed to agents.

Afterward, in periods $t>0$, wages become again fully flexible.

To understand the implications of this form of nominal wage rigidities, denote by $\hat{L}_{i, 0}^{T}$ the notional equilibrium labor in the traded sector that would prevail in country $i$ and period $t=0$ in the absence of the shock to the borrowing limit, that is in the initial steady state. Wages

${ }^{33}$ To see this point, consider that the Euler equation for bonds denominated in units of currency is

$$
\frac{U_{C_{i, t}^{T}}}{R_{t}^{N} P_{t}^{T}}=\beta E_{t}\left[\frac{1}{P_{t+1}^{T}}\left(U_{C_{i, t+1}^{T}}+\mu_{i, t}\right)\right],
$$

while the Euler equation for bonds denominated in units of tradables is

$$
\frac{U_{C_{i, t}^{T}}}{R_{t}}=\beta E_{t}\left[U_{C_{i, t+1}^{T}}\right]+\mu_{i, t} .
$$

In absence of unexpected movements in the price of the tradable good we can write $R_{t}=R_{t}^{N} P_{t}^{T} / P_{t+1}^{T}$ and verify that the two Euler equations are identical and the two assets are perfect substitutes.

${ }^{34}$ Section 6 introduces a model in which wage rigidities last longer than a single period. 
are then set according to

$$
W_{i, 0}=\alpha_{T} A_{i, 0}^{T} E_{-1}\left[P_{0}^{T}\right]\left(\hat{L}_{i, 0}^{T}\right)^{\alpha_{T}-1}
$$

Once wages are set, equilibrium labor is determined by firms' labor demand. Combining the expression for wages and firms' labor demand gives

$$
L_{i, 0}^{T}=\left(\frac{P_{0}^{T}}{E_{-1}\left[P_{0}^{T}\right]}\right)^{\frac{1}{1-\alpha_{T}}} \hat{L}_{i, 0}^{T} .
$$

Hence, the assumptions about wage setting imply that on impact the shock to the borrowing limit affects equilibrium labor in the tradable sector only if it induces unexpected movements in the nominal price of the traded good.

Figure 5 shows how the monetary union with nominal wage rigidities responds to a tightening of the borrowing limit. As in the previous section, in period $t=0$ the union is subject to an unexpected permanent drop in the borrowing limit, such that the final borrowing limit is equal to 75 percent of the initial one. This triggers a process of deleveraging that leads to a progressive reduction in the world debt-to-GDP ratio, as shown by the top-right panel of figure 5 .

The bottom-left panel of the figure shows the response of the interest rate. ${ }^{35}$ For ease of comparison, the figure shows both the path of the interest rate in the economy with flexible wages, the solid line, as well as the response of the interest rate in the monetary union with nominal wage rigidities, the dashed line. As it happened with flexible wages, deleveraging triggers a fall in the world interest rate. However, quantitatively the fall in the interest rate is much larger in a monetary union. In fact, in the model with flexible wages the interest rate falls on impact by around 2.5 percentage points. Instead, in a monetary union with nominal wage rigidities the fall in the interest rate is three times larger, since it goes from 2.5 percent to around -5 percent. Hence, in a monetary union the combination of nominal wage rigidities and fixed exchange rates amplifies the fall in the interest rate following a deleveraging shock.

To gain intuition about this effect, it is useful to look at the behavior of high-debt borrowingconstrained countries. Figure 6 displays the impact responses of the current account-to-GDP ratio, the output and consumption of the traded good and the output of the non-traded good across the initial distribution of net foreign assets. As it happened in the previous section, highdebt countries are forced to improve their current account by the tightening of the constraint.

\footnotetext{
${ }^{35}$ Notice that, since inflation in the tradable sector is zero, the interest rate displayed in figure 5 can be interpreted both as the nominal rate or as the real rate, defined as the nominal rate deflated by inflation in the tradable sector.
} 


\section{Borrowing limit}

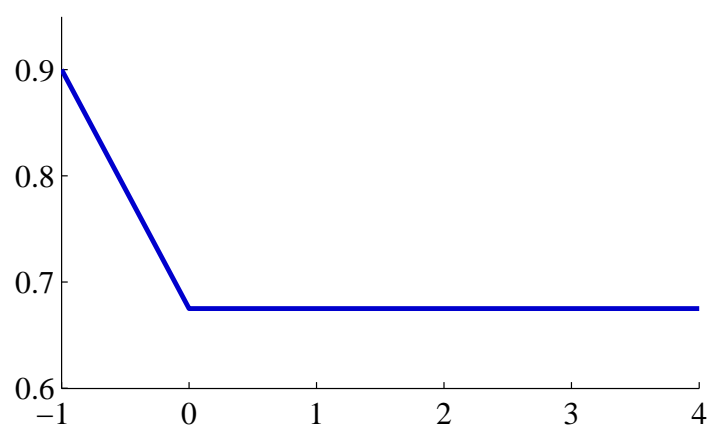

Interest rate

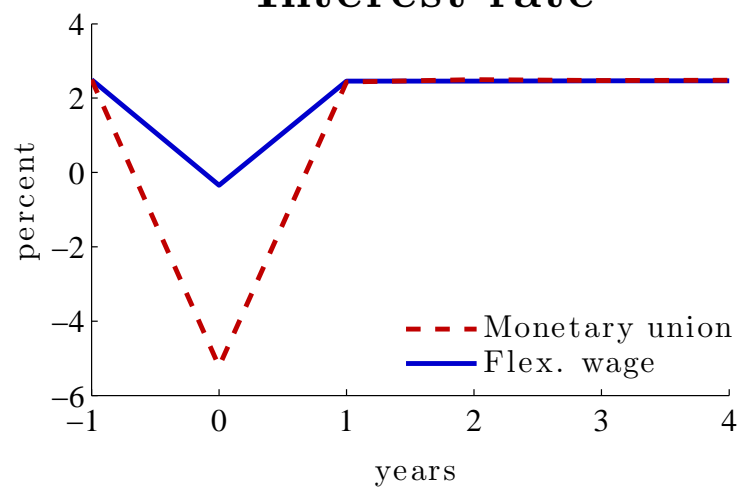

World debt/GDP

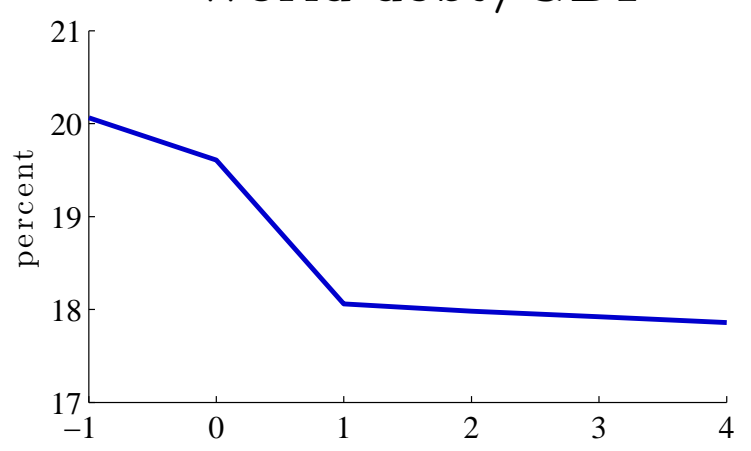

World output

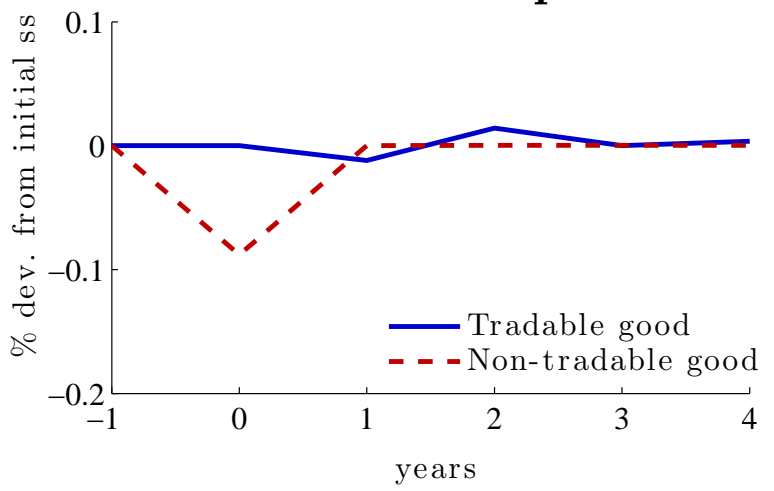

Figure 5: Response to deleveraging shock - monetary union with nominal wage rigidities. Note: Since inflation in the tradable sector is zero, the interest rate can be interpreted both as the nominal rate or as the real rate, defined as the nominal rate deflated by inflation in the tradable sector.

However, in a monetary union with nominal wage rigidities improving the current account through an increase in the production of the traded good is no longer an option, In fact, given that nominal wages do not adjust, this would require a nominal exchange rate depreciation, which is ruled out by the participation in the monetary union. This is illustrated by the topright panel of figure 6 , which shows that the combination of nominal wage rigidities and fixed exchange rates shuts down the response of the output of tradable goods to the deleveraging shock. ${ }^{36}$

It follows that the improvement in the current account in high-debt countries has to come solely through a cut in the consumption of the tradable good. In fact, the bottom-left panel of figure 6 shows that high-debt economies adjust through deep cuts in the consumption of the traded good. The fact that constrained countries have to adjust exclusively through a cut in consumption implies a bigger fall in the demand for consumption compared to the world with flexible wages. In turn, the interest rate has to fall by more to induce unconstrained countries to increase consumption and pick up the slack left by constrained economies. Hence,

\footnotetext{
${ }^{36}$ Precisely, this happens because the central bank hits the inflation target, so $P_{0}^{T}=E_{-1}\left[P_{0}^{T}\right]$ and the pattern of production during period $t=0$ is the same as the one in the initial steady state.
} 

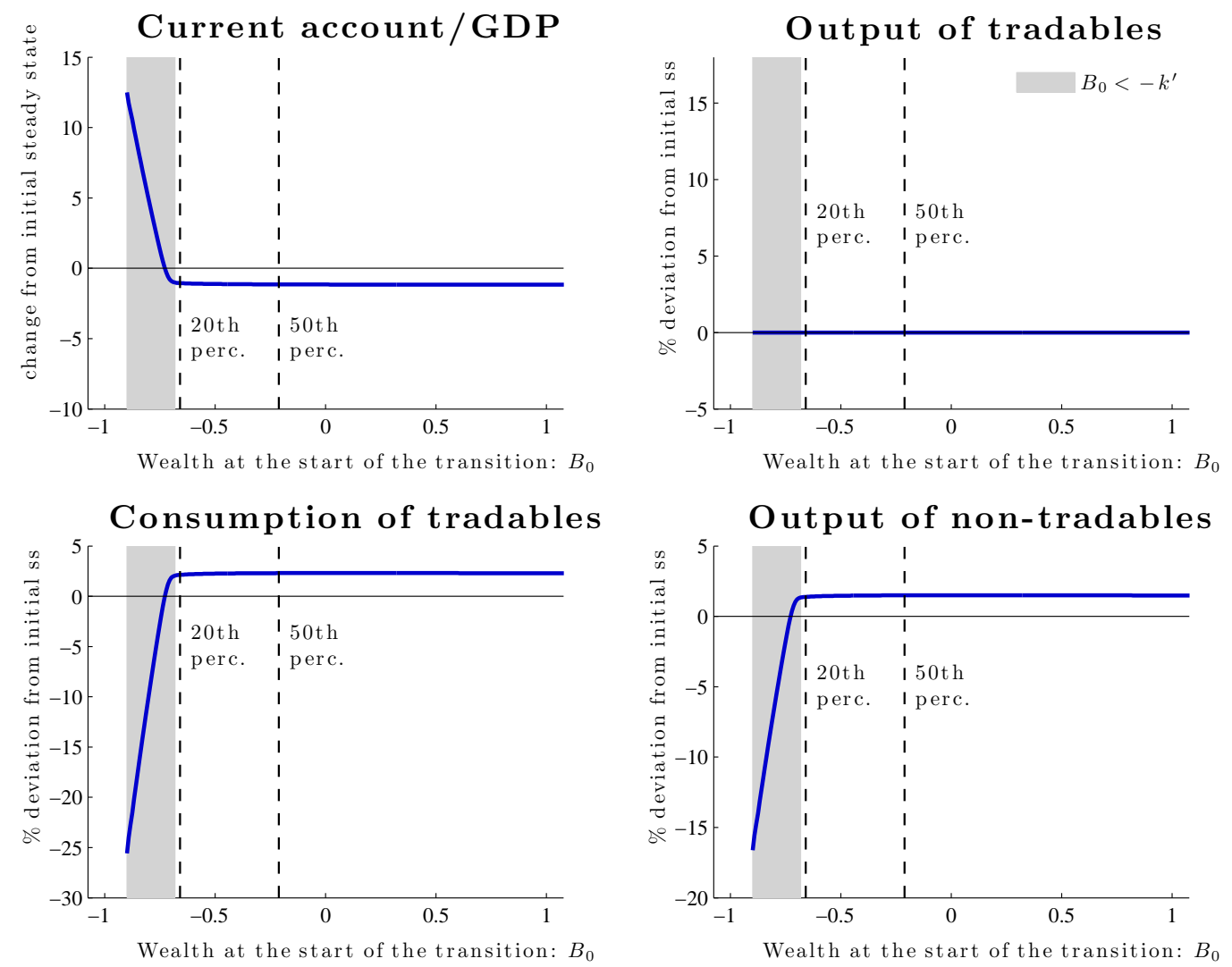

Figure 6: Impact responses to deleveraging shock across the NFA distribution - monetary union with nominal wage rigidities.

the chances that a deleveraging shock pushes the world into a liquidity trap, that is a situation in which the nominal interest rate hits the zero lower bound, are higher if countries are part of a monetary union.

Moreover, while the deleveraging shock had an expansionary effect on output in high-debt countries in the absence of nominal rigidities, this is no longer the case when wages are rigid and the nominal exchange rates cannot adjust. Indeed, on impact the deleveraging shock generates a drop in the production of non-traded goods in high-debt countries, as highlighted by the bottom-right panel of figure 6 . To understand why this happens, consider that labor demand from firms in the non-traded sector is given by

$$
L_{i, t}^{N}=\left(\alpha_{N} A^{N} \frac{P_{i, t}^{N}}{W_{i, t}}\right)^{\frac{1}{1-\alpha_{N}}}
$$

while households' optimality conditions give an expression for the nominal price of the nontradable good

$$
P_{i, t}^{N}=\frac{1-\omega}{\omega} \frac{C_{i, t}^{T}}{C_{i, t}^{N}} P_{t}^{T}
$$


The drop in the consumption of the traded good experienced by high-debt countries generates a real exchange rate depreciation, that is a fall in the relative price of non-tradables. Since the central bank strictly targets inflation in the traded sector and nominal exchange rates are fixed, the real exchange rate depreciation translates into a fall in the nominal price of the non-tradable good. Given the fixed nominal wages, this implies that employing labor in the non-traded sector becomes less profitable and firms in high-debt countries are pushed to reduce their labor demand and lower the production of the non-traded good.

The interaction between nominal wage rigidities and fixed exchange rates generates a recession in the countries that end up being financially constrained following the deleveraging shock. The next section shows how the recession can spread to unconstrained countries if the deleveraging shock pushes the union into a liquidity trap.

\section{The role of the zero lower bound}

The previous section considered a central bank freely able to set the nominal interest rate in order to hit the inflation target. In reality, nominal interest rates cannot fall below zero. This section considers explicitly the role of the zero lower bound on the nominal interest rate and shows that deleveraging can generate a union-wide recession if the zero lower bound on the interest rate becomes binding.

Define $\hat{R}_{t}^{N}$ as the nominal interest rate consistent with the central bank's inflation target. In this section the focus is on a central bank that sets the interest rate according to $R_{t}^{N}=$ $\max \left(\hat{R}_{t}^{N}, 1\right)$. This rule implies that the central bank sticks to the inflation target as long as this does not imply a negative nominal rate, otherwise it sets the nominal interest rate to zero. $^{37}$

From the analysis in the previous section we know that in $t=0$, the first period in which the borrowing limit gets tighter, the nominal interest rate consistent with zero inflation in the price of the tradable good is negative. Hence, the central bank sets $R_{0}^{N}=1$. However, at this interest rate the market for consumption of the traded good does not clear, since demand for consumption is too weak to absorb the whole production of tradables. Excess supply induces firms to cut the nominal price of the traded good until equilibrium on the traded good market is restored. We then have that the unexpected deleveraging shock triggers an unexpected fall in the nominal price of the traded good, so that $P_{0}^{T}<E_{-1}\left[P_{0}^{T}\right]$.

The unexpected fall in the nominal price of the traded good has two distinct effects. On

\footnotetext{
${ }^{37}$ Remember that $R^{N}$ denotes the gross nominal interest rate.
} 
Borrowing limit

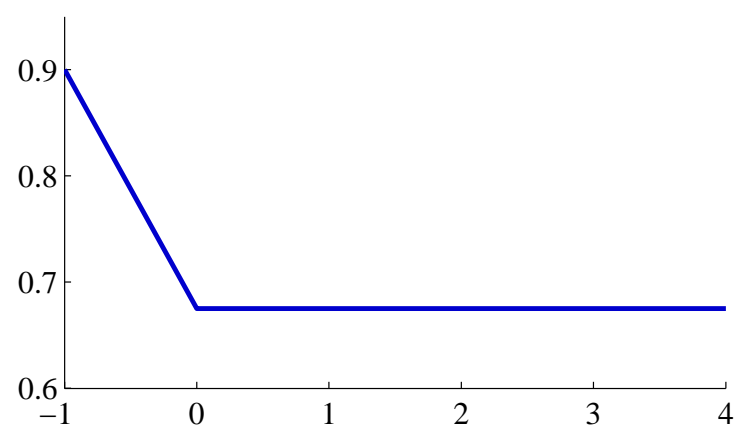

Interest rate

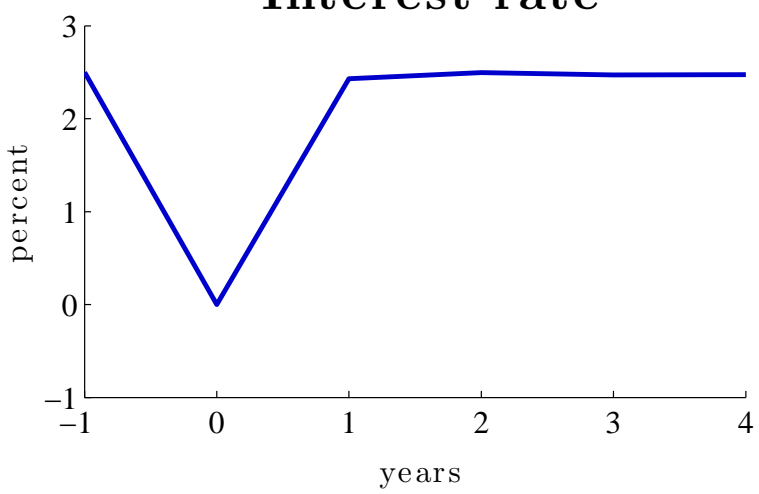

World debt/GDP

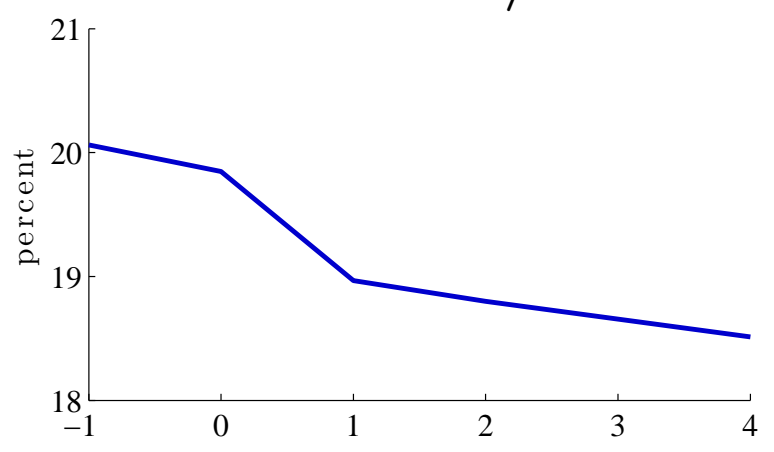

World output

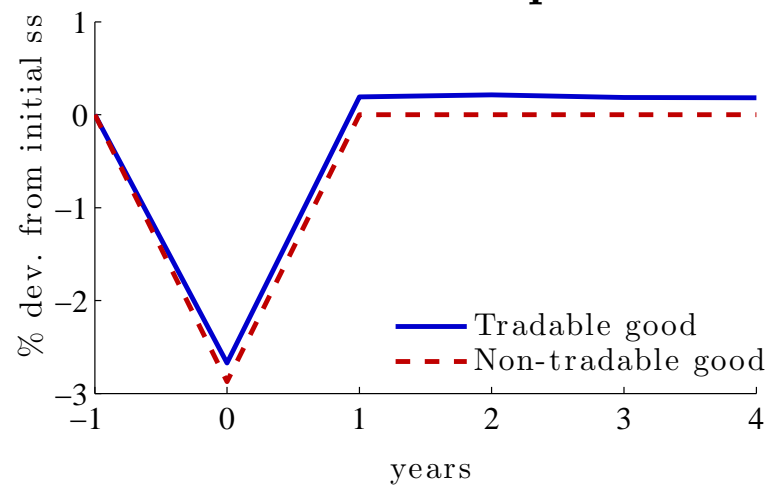

Figure 7: Response to deleveraging shock - liquidity trap in a monetary union.

the one hand, the fall in the price of the traded good reduces the profitability of employing labor in the traded sector. This leads to a fall in the world production of tradables. Indeed, this is the mechanism through which deflation in the traded sector restores equality between the demand and the supply of the traded good.

On the other hand, since bonds are denominated in units of currency, the fall in the nominal price of the traded good increases the debt burden of debtor countries in terms of the tradable consumption good, giving rise to an effect akin to Fisher's debt deflation. This unexpected wealth redistribution from debtor to creditor countries further depresses aggregate demand inside the monetary union. The result is that once the zero lower bound on the nominal interest rate is taken into account, deleveraging can push the whole monetary union into a recession.

Figure 7 illustrates this result by plotting the response of the union to the deleveraging shock in the case in which the central bank is constrained by the zero bound on the interest rate. The tightening of the borrowing limit has a depressive effect on the interest rate, which on impact hits the zero lower bound. This induces a fall in the nominal price of the tradable good. In turn, the combination of nominal wage rigidities and deflation reduces the profitability of employing labor in the tradable sector. This explains the union-wide drop in the output of 

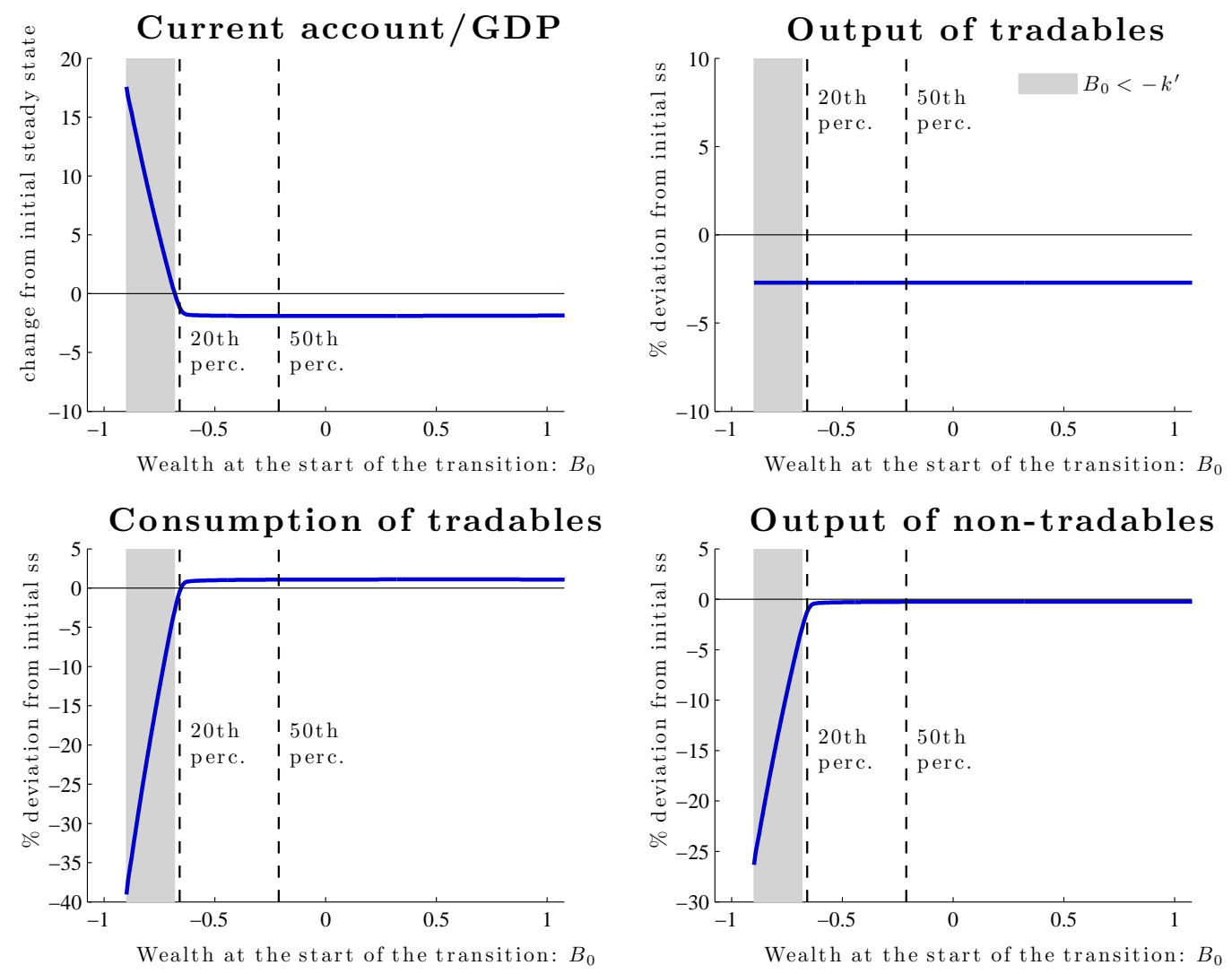

Figure 8: Impact responses to deleveraging shock across the NFA distribution - liquidity trap in a monetary union.

traded goods, which falls by almost 3 percentage points below its value in the initial steady state. Moreover, deflation in the tradable sector puts downward pressure on the nominal prices of the non-traded goods, as shown by equation (8). Deflation in the price of the non-traded good pushes firms in the non-traded sector to cut employment and production. Because of this effect also the aggregate production of non-traded goods falls.

To see how the recession affects differently the countries depending on their initial debt positions, it is useful to look at figure 8. Both high-debt and low-debt countries experience a similar fall in the output of the tradable good. This happens because the demand for the traded good, and so its price, depends on the demand from all the countries in the union.

The consumption of the traded good exhibits a different pattern. In fact, the countries featuring a high initial debt experience deep falls in the consumption of the traded good, much larger than the one experienced in the absence of the zero lower bound. This happens because constrained countries have a high propensity to consume out of current income. Hence, the fall in the production of tradables directly translates into a fall in consumption. In addition, deflation increases the initial debt position of debtor countries, the Fisher's debt deflation effect, and this further depresses their consumption of tradable goods. 
Concerning the production of non-tradables, figure 8 shows that high-debt countries exhibit deep falls in employment and output in the non-traded sector. As before, this happens because the fall in the consumption of the traded good generates a real exchange rate depreciation. Since the nominal exchange rate cannot adjust, the real depreciation results in a fall in the nominal price of non-tradables. Given the fixed wages, deflation in the non-traded sector induces a fall in employment. The result is that the whole union enters a recession, but the crisis hits particularly hard the non-traded sectors in high-debt countries.

\section{$6 \quad$ Policy implications}

\subsection{A model with multi-period wage rigidities}

Which policy interventions can mitigate the recession associated with deleveraging inside a monetary union? I address this question using the model as a laboratory to perform policy experiments. This section considers a version of the model parameterized at quarterly frequency in which the adjustment to the deleveraging shock lasts more than one period and dynamic effects take the center stage. Indeed, whenever a liquidity trap lasts more than one period strong amplification effects are set in motion, so a quarterly parametrization is better suited to capture the quantitative implications of the model.

As a first step, I introduce a dynamic process of wage adjustment in which nominal rigidities last more than a single period. As in the previous section, I still assume than in the first period in which the borrowing limit gets tighter, $t=0$, nominal wages are fully rigid. As in the previous section, in $t=0$ nominal wages are set after the realization of the idiosyncratic productivity shocks, but before the shock to the borrowing limit is revealed to agents. The difference is that now in $t>0$ wages are no longer fully flexible, but evolve according to

$$
W_{i, t}=\left(W_{i, 0} \pi^{t}\right)^{\phi_{t}}\left(W_{i, t}^{f l e x}\right)^{1-\phi_{t}}
$$

This expression implies that the nominal wage in period $t$ in country $i$ is a weighted average of the nominal wage in country $i$ in period $t=0, W_{i, 0}$, and of the wage that would clear the market for labor, $W_{i, t}^{f l e x}{ }^{38}$ This reduced form captures in a simple way a case in which every

\footnotetext{
${ }^{38}$ Formally, $W_{i, t}^{\text {flex }}$ is defined as the wage that equates the marginal disutility of labor to the marginal benefit that the household gets from working more

$$
W_{i, t}^{f l e x}=-\frac{U_{L_{i, t}}}{U_{C_{i, t}^{T}}^{T}} P_{t}^{T}
$$
}


Table 2: Parameters (quarterly)

\begin{tabular}{lll}
\hline & Value & Source/Target \\
\hline Discount factor & $\beta=0.9938$ & $R=1.025$ (annualized) \\
TFP process & $\sigma_{A^{T}}=0.0106, \rho=0.9573$ & Benigno and Thoenissen (2008) \\
Initial borrowing limit & $\kappa=3.24$ & World debt/GDP $=80 \%$ \\
Final borrowing limit & $\kappa^{\prime}=2.43$ & World debt/GDP $=60 \%$ \\
Target for trad. inflation & $\pi=2 \%$ & Standard value (annualized) \\
\hline
\end{tabular}

period only part of the wages are adjusted. The fraction of the wages that do not adjust are indexed on the inflation target in the tradable sector, $\pi$. The weights given to rigid wages, $\phi_{t}$, declines linearly over time

$$
\phi_{t}=\max \left\{0, \phi_{0}-\Delta t\right\}
$$

so that in the long run wages become fully flexible. ${ }^{39}$ The parameter $\Delta$ is set so that complete wage flexibility is reached after two years, or eight quarters.

To focus on dynamics effects, the version of the model presented in this section is parameterized at quarterly frequency. Table 2 displays the value of the parameters that change with respect to the annual parametrization used in the previous sections. The discount factor $\beta$ is adjusted so as to target an annualized real interest rate in the initial steady state of 2.5 percent. Also, the parameters governing the TFP process are adjusted so that TFP in the tradable sector exhibits the same persistence and standard deviation as in the annual parametrization, once it is aggregated annually. ${ }^{40}$

The borrowing limit in the initial steady state is set to $\kappa=3.24$ to target a world gross debt-to-GDP ratio of 80 percent. This is the same target as in the annual calibration, taking into account the fact that now GDP in each period corresponds to quarterly GDP in the data. Accordingly, the borrowing limit in the final steady state is set to $\kappa^{\prime}=2.43$ to target a ratio of gross debt-to-GDP in the final steady state of 60 percent. Finally, the inflation target in the tradable sector is set to 2 percent per year, in line with the definition of price stability given by the FED and the ECB.

In this section, consistent with the model with annual parametrization, the borrowing limit

\footnotetext{
${ }^{39}$ This assumption is akin to abstracting from the impact of wage rigidities on normal business cycles, driven by the productivity shocks, in order to fully concentrate on their interaction with the deleveraging shock.

${ }^{40}$ To convert the parameters from annual to quarterly frequency I use the following formulas

$$
\begin{gathered}
\rho=\rho_{a}^{\frac{1}{4}} \\
\sigma_{A^{T}}^{2}=\frac{8\left(1-\rho^{2}\right)}{2+3 \rho+2 \rho^{2}+\rho^{3}} \frac{\sigma_{A^{T}, a}^{2}}{1-\rho_{a}^{2}},
\end{gathered}
$$
}

where the $a$ subscript denotes annual parameters. 
Borrowing limit

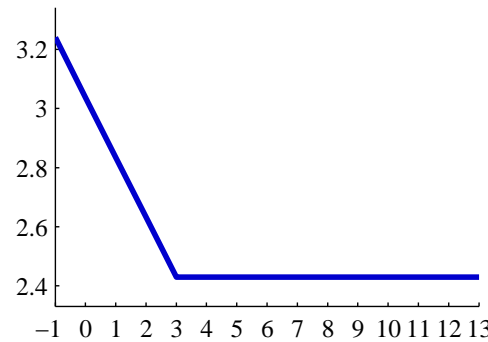

Consumer price index

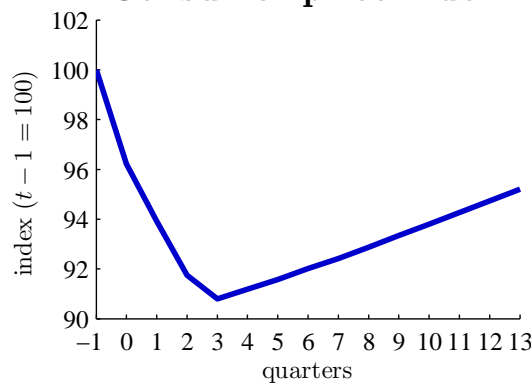

World debt/GDP

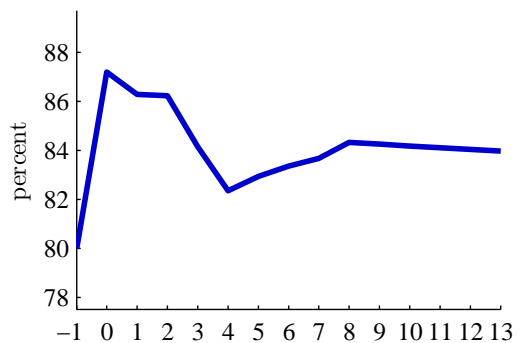

Real interest rate

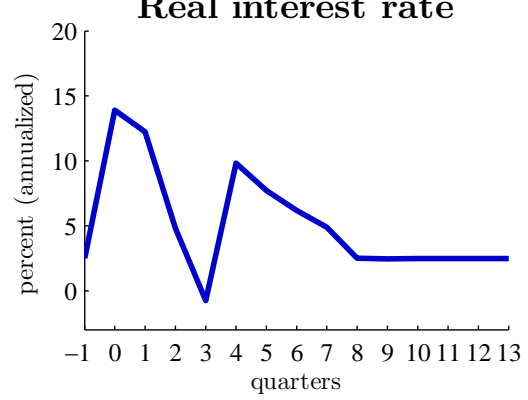

Nominal interest rate

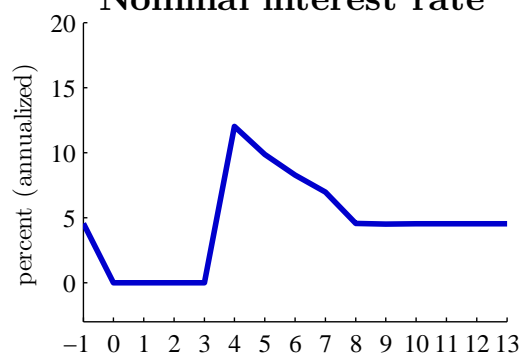

World output

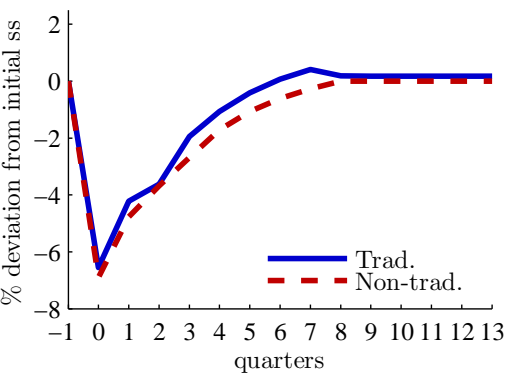

Figure 9: Response to deleveraging shock - multi-period liquidity trap. Note: Consumer price index denotes the monetary union aggregate consumer price index. The real interest rate is the nominal interest rate deflated by inflation in the tradable sector.

takes one year to reach its lower value in the new steady state, $\kappa^{\prime} \cdot{ }^{41}$ In particular, I assume that from period $t=0$ on the borrowing limit follows the linear adjustment path

$$
\kappa=\max \left\{\kappa^{\prime}, \kappa-\Delta_{\kappa} t\right\}
$$

The parameter $\Delta_{\kappa}$ is chosen so that it takes four quarters, or one year, for the borrowing limit to reach its new steady state value. As before, the initial fall in the borrowing limit happening in $t=0$ is not anticipated by agents, while from period $t=0$ on agents correctly anticipate the path of adjustment of the borrowing limit.

Figure 9 illustrates the transitional dynamics after a shock to the borrowing limit for the model with multi-period wage rigidities. In period $t=0$, the monetary union is hit by an unexpected tightening of the borrowing limit that reaches its new steady state value in four quarters. The deleveraging shock induces agents to increase savings and reduce the demand for consumption, driving down the interest rate. In response, the central bank lowers the nominal interest rate to zero in an attempt to hit the inflation target and the economy enters a liquidity trap that starts in period $t=0$ and lasts four quarters. Since the nominal interest rate cannot

\footnotetext{
${ }^{41}$ In addition to comparability with the results presented in the previous sections, one reason to consider a gradual adjustment of the borrowing limit is the fact that the model features only debt contracts that last one period, that is one quarter. In reality, debt can take maturities that are longer than one quarter. Considering a gradual adjustment in the borrowing limit is a simple way of capturing the fact that long term debt allows agents to adjust gradually to the new, tighter, credit conditions.
} 
go low enough to guarantee market clearing, prices fall to restore equality between demand and supply. This is illustrated by the bottom-left panel of figure 9, which shows the path of the monetary union aggregate consumer price index (CPI). ${ }^{42}$ Deflation leads to an increase in the world real interest rate that further depresses consumption demand leading to even more deflation. ${ }^{43}$ This amplification effect, which is not present when the liquidity trap lasts just one period, sharpens the recession. In fact, the fall in nominal prices is not matched by an equivalent fall in nominal wages. This reduces profits and induces firms to cut employment and production both in the tradable and in the non-tradable sector.

The result is a prolonged recession that affects all the countries belonging to the monetary union. Quantitatively, the recession is particularly severe during the first year following the deleveraging shock. In fact, on impact world output of the traded good falls by almost 7 percentage points below its value in the initial steady state, and after one year, in period $t=3$, it is still more than 3 percentage points below trend. Also the world output of non-tradables exhibits a large fall during the first year of deleveraging. In addition, the deleveraging process does not follow a monotonic pattern, as it happened before. Instead, initially the debt-to-GDP ratio rises due to the sharp fall in GDP. Only starting from the second quarter the ratio of gross world debt-to-GDP declines. ${ }^{44}$

Once the liquidity trap is over, in period $t=4$, the central bank raises the nominal interest rate above its value in the new steady state. This happens because the fall in prices coupled with nominally rigid wages keeps supply subdued, until wage flexibility is restored. Instead, after four quarters of deleveraging the debt overhang is reduced and aggregate demand recovers. The combination of low supply and high demand puts upward pressure on prices, so the central bank has to raise nominal rates in order to dampen the rise in consumption demand and to prevent inflation from exceeding the 2 percent inflation target. This explains the slow recovery that takes two years to complete.

\footnotetext{
${ }^{42}$ Formally, the CPI in a generic country $i$ is defined as the minimum price of a unit of the consumption basket $C_{i}$

$$
C P I_{i, t}=\omega^{-\omega}(1-\omega)^{\omega-1}\left(P_{t}^{T}\right)^{\omega}\left(P_{i, t}^{N}\right)^{1-\omega}
$$

The aggregate CPI of the monetary union is defined as $C P I_{t}=\int_{0}^{1} C P I_{i, t} \mathrm{~d} i$.

${ }^{43}$ For consistency with the previous sections, the real rate is defined as the nominal rate deflated by inflation in the traded sector. However, quantitatively the difference between inflation in the traded sector and CPI inflation are negligible.

${ }^{44}$ This is consistent with the path of the private debt-to-GDP ratio observed during several deleveraging episodes. See McKinsey (2010, 2012).
} 

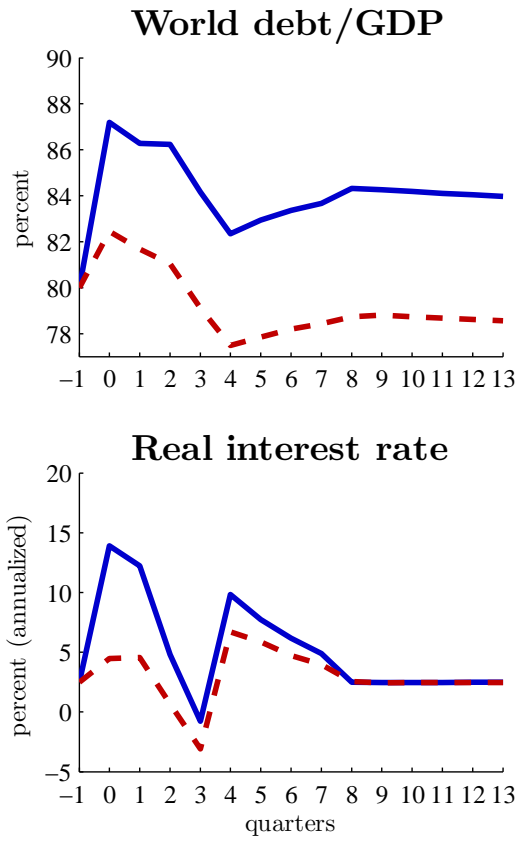

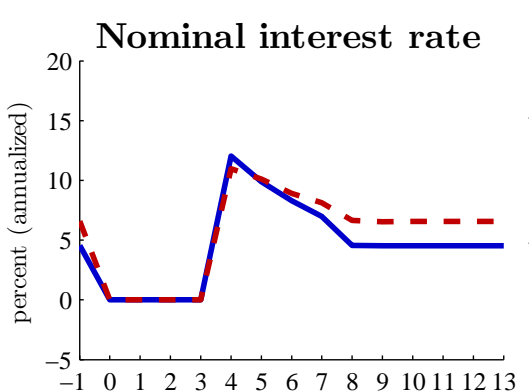

World output - tradables

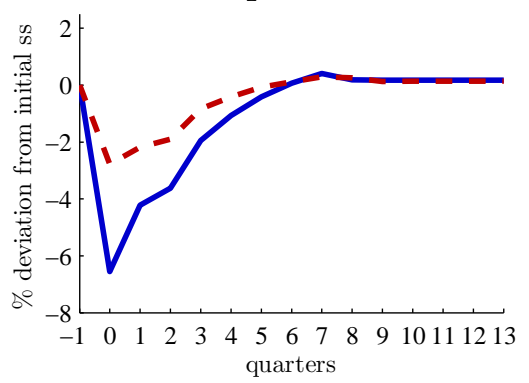

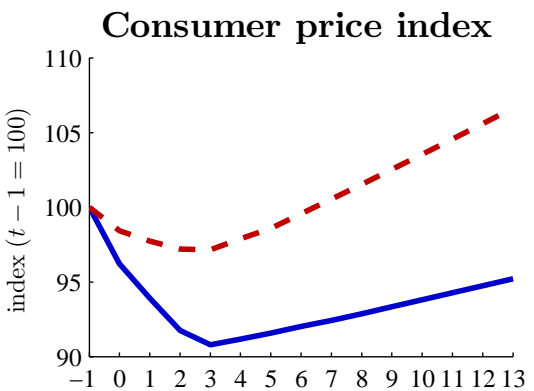

World output - non-trad.

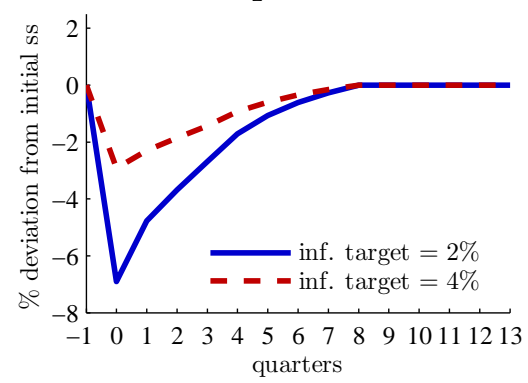

Figure 10: Response to deleveraging shock - higher inflation target. Note: Consumer price index denotes the monetary union aggregate consumer price index. The real interest rate is the nominal interest rate deflated by inflation in the tradable sector.

\subsection{Raising the inflation target}

One policy that can mitigate the recession during debt deleveraging consists in adopting a higher inflation target. Figure 10 compares two monetary unions with different steady state inflation targets. ${ }^{45}$ The solid lines refer to the baseline economy, in which the inflation target is 2 percent a year, while the dashed lines refer to an economy with a higher inflation target, of 4 percent a year.

Even with a 4 percent inflation target the deleveraging shock pushes the monetary union into a liquidity trap that lasts four quarters. However, the adjustment is much less traumatic in the economy with higher inflation target. In fact, a higher inflation target guarantees a smaller drop in output, as well as less deflation and lower real rates throughout the liquidity trap. The reason is the following. In the last period of the liquidity trap, period $t=3$, the real interest rate, defined as the nominal interest rate deflated by inflation in the tradable sector, is equal to the inverse of the inflation target. This happens because the nominal interest rate is equal to zero, so the real rate is equal to the inverse of the inflation rate. Since the central bank hits the inflation target once the liquidity trap is over, the expected inflation in period

\footnotetext{
${ }^{45}$ This section looks at two economies whose steady state inflation target is different. An alternative would be to consider a change in the inflation target in response to the tightening of the borrowing limit. However credibility issues are likely to prevent a central bank from changing the inflation target in the middle of a deleveraging episode. This point is discussed by Eggertsson (2008), who considers credibility issues faced by the FED during the Great Depression.
} 
Borrowing limit
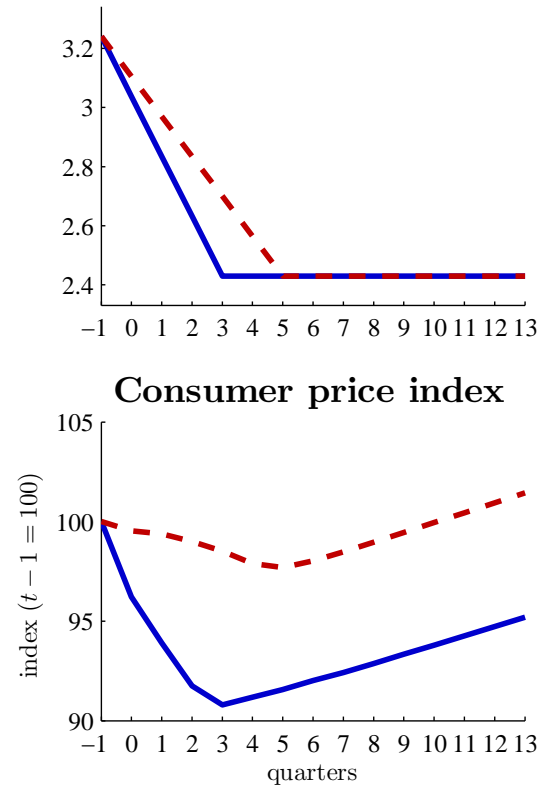

World debt/GDP

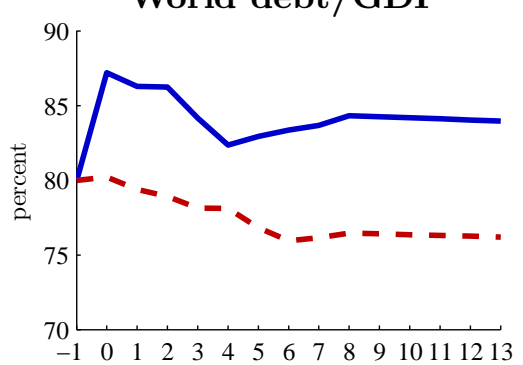

World output - tradables

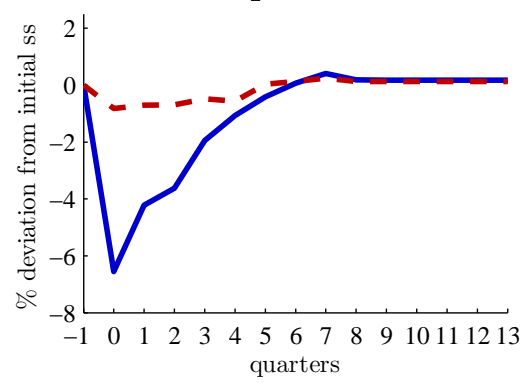

Nominal interest rate

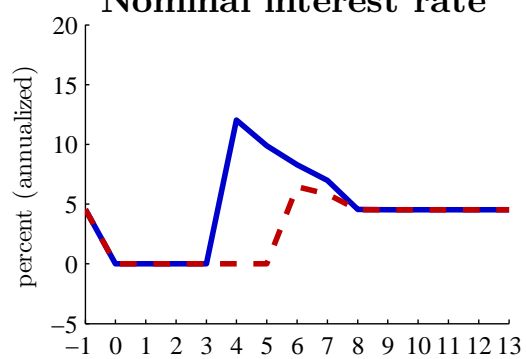

World output - non-trad.

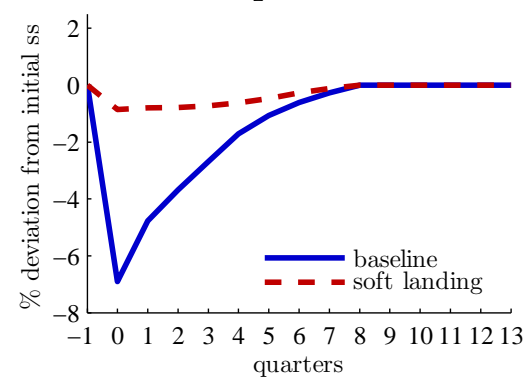

Figure 11: Response to deleveraging shock - soft landing. Note: Consumer price index denotes the monetary union aggregate consumer price index.

$t=3$ is equal to the inflation target. This means that the real interest rate in the last period of the liquidity trap is lower the higher the inflation target.

A lower real rate stimulates demand for consumption in the last period of the trap, limiting the fall in prices and the contraction in output. Moreover, the lower real rate in the last period of the trap has also a positive effect on demand during the previous periods, since aggregate demand depends on the path of all the future interest rates. It follows that during the previous periods too deflation is lower and the drop in output is smaller. Indeed, raising the inflation target from 2 to 4 percent halves the fall in output during the liquidity trap. This experiment suggests that a higher inflation target may be helpful in limiting the recession during a deleveraging episode in a monetary union.

\subsection{A "soft landing" scenario}

In the first phase of the 2008/2009 recession, public flows passing via the ECB played a major role in cushioning the fall in foreign credit in the countries at the Eurozone periphery, as shown by Lane and Milesi-Ferretti (2012). In this section I consider a simple experiment to evaluate the effectiveness of policies that slow down the adjustment in debtor countries, inducing a "soft landing" type of adjustment. More precisely, I compare the baseline scenario in which the borrowing limit takes four quarters to reach its new steady state value, to an economy in which the borrowing limit takes six quarters to reach its new steady state value. The results 
are shown in figure 11. The solid lines refer to the baseline economy, while the dashed lines refer to the soft landing scenario.

Figure 11 makes clear that the intervention aiming at slowing the adjustment to the new credit conditions significantly reduces deflation and the output contraction. This happens because a gradual tightening of the borrowing limit prevents abrupt cuts in consumption and reduces the fall in the interest rate needed to reach market clearing. So, although now the liquidity trap lasts six quarters, two quarters more than in the baseline scenario, the adjustment is smoother and the recession is milder. Moreover, in the soft landing scenario deleveraging, as captured by the reduction in the world debt-to-GDP ratio, is faster. This happens because the slower adjustment in the borrowing limit prevents the sharp fall in GDP that causes the initial rise in the world debt-to-GDP ratio in the baseline economy.

This experiment suggests that interventions that limit the surprise effect of a deleveraging shock can play a role in mitigating the recession associated with an episode of debt deleveraging.

\section{Conclusion}

I propose a multi-country model for understanding deleveraging among a group of financially integrated countries. The model highlights a novel economic mechanism that makes episodes of debt deleveraging particularly painful for monetary unions. Deleveraging leads to a drop in the world interest rate, both because high-debt countries are forced to save more in order to reduce their debt and because the rest of the world experiences an increase in the desire to accumulate precautionary savings. In the absence of nominal rigidities, deleveraging also triggers a rise in production in high-debt countries. If wages are nominally rigid but nominal exchange rates are allowed to float, the rise in production involves a nominal depreciation in high-debt countries. In a monetary union, the combination of nominal wage rigidities and fixed exchange rates prevents any increase in production in indebted countries. This amplifies the fall in the world consumption demand and the drop in the world interest rate. Hence, monetary unions are particularly prone to enter a liquidity trap during an episode of deleveraging. In a liquidity trap deleveraging generates a deflationary union-wide recession, hitting high-debt countries especially hard.

The analysis presented in this paper can be extended in a number of directions. First, the model could be used to understand the role of fiscal policy in a monetary union undergoing a process of deleveraging. In particular, the recent experience of the Eurozone has sparked a lively debate on the role of fiscal transfers and mutual insurance inside monetary unions. The 
model has the potential to shed light on this key policy issue, and I plan to tackle it in future research. In addition, it would be interesting to consider collateral constraints in which asset prices, for instance house prices, play a role in determining access to credit. Mendoza (2010) uses a small open economy model to show how economies in which borrowing depends on the price of capital can endogenously enter deleveraging episodes. An open research question concerns the interactions between these types of constraints and the zero lower bound in a model of the world economy. ${ }^{46}$

\footnotetext{
${ }^{46}$ See Fornaro (2012) for a small open economy model in which nominal wage rigidities and exchange rate policies interact with occasionally binding collateral constraints.
} 


\section{References}

Aiyagari, S.R. (1994) "Uninsured idiosyncratic risk and aggregate saving," The Quarterly Journal of Economics, Vol. 109, No. 3, pp. 659-684.

Bai, Y. and J. Zhang (2010) "Solving the Feldstein-Horioka puzzle with financial frictions," Econometrica, Vol. 78, No. 2, pp. 603-632.

Barattieri, A., S. Basu, and P. Gottschalk (2010) "Some evidence on the importance of sticky wages," NBER Working Paper No. 16130.

Benigno, G. and C. Thoenissen (2008) "Consumption and real exchange rates with incomplete markets and non-traded goods," Journal of International Money and Finance, Vol. 27, No. 6, pp. 926-948.

Benigno, P. (2004) "Optimal monetary policy in a currency area," Journal of International Economics, Vol. 63, No. 2, pp. 293-320.

Benigno, P. and F. Romei (2012) "Debt Deleveraging and the Exchange Rate," NBER Working Paper No. 17944.

Bernanke, B.S. and K. Carey (1996) "Nominal wage stickiness and aggregate supply in the Great Depression," The Quarterly Journal of Economics, Vol. 111, No. 3, pp. 853-883.

Bewley, T. (1977) "The Permanent Income Hypothesis and Welfare Economics," Journal of Economics Theory, Vol. 16, No. 2, pp. 252-292.

Bordo, M.D., C.J. Erceg, and C.L. Evans (2000) "Money, Sticky Wages, and the Great Depression," American Economic Review, Vol. 90, No. 5.

Carroll, C., J. Slacalek, and M. Sommer (2012) "Dissecting Saving Dynamics: Measuring Wealth, Precautionary, and Credit Effects," Unpublished Manuscript.

Carroll, C.D. (1997) "Buffer-stock saving and the life cycle/permanent income hypothesis," The Quarterly Journal of Economics, Vol. 112, No. 1, pp. 1-55.

(2006) "The method of endogenous gridpoints for solving dynamic stochastic optimization problems," Economic Letters, Vol. 91, No. 3, pp. 312-320.

Castro, R. (2005) "Economic development and growth in the world economy," Review of Economic Dynamics, Vol. 8, No. 1, pp. 195-230.

Challe, E. and X. Ragot (2012) "Precautionary saving over the business cycle," Unpublished Manuscript.

Chang, Y., S.B. Kim, and J. Lee (2009) "Accounting for global dispersion of current accounts," IMF Working Paper. 
Chari, V. V., P. J. Kehoe, and E. R. McGrattan (2005) "Sudden stops and output drops," The American Economic Review, Vol. 95, No. 2, pp. 381-387.

Christiano, L.J., M. Eichenbaum, and C.L. Evans (2005) "Nominal rigidities and the dynamic effects of a shock to monetary policy," Journal of political Economy, Vol. 113, No. 1, pp. $1-45$.

Clarida, R.H. (1990) "International lending and borrowing in a stochastic, stationary equilibrium," International Economic Review, Vol. 31, No. 3, pp. 543-558.

Cook, D. and M.B. Devereux (2011) "Sharing the burden: monetary and fiscal responses to a world liquidity trap," NBER Working Paper No. 17131.

Corsetti, G., L. Dedola, and S. Leduc (2008) "International risk sharing and the transmission of productivity shocks," Review of Economic Studies, Vol. 75, No. 2, pp. 443-473.

Deaton, A. (1991) "Saving and liquidity constraints," Econometrica, Vol. 59, No. 5, pp. 12211248.

Eggertsson, G. (2008) "Great Expectations and the End of the Depression," The American Economic Review, Vol. 98, No. 4, pp. 1476-1516.

Eggertsson, G. and P. Krugman (2012) "Debt, deleveraging, and the liquidity trap: a FisherMinsky-Koo approach," The Quarterly Journal of Economics, Vol. 127, No. 3, pp. 1469-1513.

Eggertsson, G. and M. Woodford (2003) "The zero bound on interest rates and optimal monetary policy," Brookings Papers on Economic Activity, Vol. 2003, No. 1, pp. 139-211.

Eichengreen, B. and J. Sachs (1985) "Exchange Rates and Economic Recovery in the 1930s," The Journal of Economic History, Vol. 45, No. 4, pp. 925-946.

Fabiani, S., C. Kwapil, T. Rõõm, K. Galuscak, and A. Lamo (2010) "Wage rigidities and labor market adjustment in Europe," Journal of the European Economic Association, Vol. 8, No. 2-3, pp. 497-505.

Farhi, E., G. Gopinath, and O. Itskhoki (2011) "Fiscal devaluations," NBER Working Paper No. 17662.

Fehr, E. and L. Goette (2005) "Robustness and real consequences of nominal wage rigidity," Journal of Monetary Economics, Vol. 52, No. 4, pp. 779-804.

Feldstein, M. (2010) "Let Greece take a Holiday from the Euro Zone," Financial Times.

Fisher, I. (1933) "The Debt-Deflation Theory of Great Depressions," Econometrica, Vol. 1, No. 4, pp. 337-357. 
Flodén, M. (2008) "A note on the accuracy of Markov-chain approximations to highly persistent AR (1) processes," Economics Letters, Vol. 99, No. 3, pp. 516-520.

Fornaro, L. (2012) "Financial crises and exchange rate policy," Unpublished Manuscript.

Gali, J. and T. Monacelli (2008) "Optimal monetary and fiscal policy in a currency union," Journal of International Economics, Vol. 76, No. 1, pp. 116-132.

Gottschalk, P. (2005) "Downward nominal-wage flexibility: real or measurement error?" Review of Economics and Statistics, Vol. 87, No. 3, pp. 556-568.

Guerrieri, V. and G. Lorenzoni (2011) "Credit crises, precautionary savings, and the liquidity trap," NBER Working Paper No. 17583.

(2012) "Liquidity and Trading Dynamics," Econometrica, Vol. 77, No. 6, pp. 17511790.

Hall, R.E. (2011) "The Long Slump," American Economic Review, Vol. 101, No. April, pp. $431-469$.

Huggett, M. (1993) "The risk-free rate in heterogeneous-agent incomplete-insurance economies," Journal of economic Dynamics and Control, Vol. 17, No. 5-6, pp. 953-969.

Jeanne, O. (2009) "The global liquidity trap," Unpublished Manuscript.

Kimball, M.S. and M.D. Shapiro (2008) "Labor Supply: Are the Income and Substitution Effects Both Large or Both Small?," NBER Working Paper No. 14208.

Krugman, P. (1998) "It's baaack: Japan's slump and the return of the liquidity trap," Brookings Papers on Economic Activity, Vol. 1998, No. 2, pp. 137-205.

(2010) "The Making of a Euromess," New York Times Op-Ed.

Krusell, P. and A.A. Smith, Jr (1998) "Income and wealth heterogeneity in the macroeconomy," Journal of Political Economy, Vol. 106, No. 5, pp. 867-896.

Lane, P.R. and G.M. Milesi-Ferretti (2007) "The external wealth of nations mark II: Revised and extended estimates of foreign assets and liabilities, 1970-2004," Journal of International Economics, Vol. 73, No. 2, pp. 223-250.

(2012) "External adjustment and the global crisis," Journal of International Economics, p. In press.

McKinsey, Global Institute (2010) "Debt and deleveraging: The global credit bubble and its economic consequences."

(2012) "Debt and deleveraging: Uneven progress on the path to growth." 
Mendoza, E.G. (2010) "Sudden stops, financial crises, and leverage," The American Economic Review, Vol. 100, No. 5, pp. 1941-1966.

Mian, A., K. Rao, and A. Sufi (2011) "Household Balance Sheets, Consumption, and the Economic Slump," Unpublished Manuscript.

Mian, A. and A. Sufi (2012) "What explains high unemployment? The aggregate demand channel," NBER Working Paper No. 17830.

Michaillat, P. (2012) "Do matching frictions explain unemployment? Not in bad times," The American Economic Review, Vol. 102, No. 4, pp. 1721-1750.

Midrigan, V. and T. Philippon (2011) "Household Leverage and the Recession," NBER Working Paper No. 16965.

Mody, A., F. Ohnsorge, and D. Sandri (2012) "Precautionary savings in the Great Recession," IMF Economic Review, Vol. 60, No. 1, pp. 114-138.

Nakamura, E. and J. Steinsson (2011) "Fiscal stimulus in a monetary union: Evidence from US regions," NBER Working Paper No. 17391.

Olivei, G. and S. Tenreyro (2007) "The timing of monetary policy shocks," The American Economic Review, pp. 636-663.

(2010) "Wage-setting patterns and monetary policy: International evidence," Journal of monetary economics, Vol. 57, No. 7, pp. 785-802.

Perri, F. and V. Quadrini (2011) "International recessions," NBER Working Paper No. 17201.

Schmitt-Grohé, S. and M. Uribe (2011) "Pegs and Pain," NBER Working Paper No. 16847.

Shimer, R. (2010) "Wage rigidities and jobless recoveries," Unpublished Manuscript.

Stockman, A.C. and L.L. Tesar (1995) "Tastes and Technology in a Two-Country Model of the Business Cycle: Explaining International Comovements," The American Economic Review, Vol. 85, No. 1, pp. 168-185.

Svensson, L. (2003) "Escaping from a liquidity trap and deflation: the foolproof way and others," Journal of Economic Perspectives, Vol. 17, No. 4, pp. 145-166.

Tauchen, G. and R. Hussey (1991) "Quadrature-based methods for obtaining approximate solutions to nonlinear asset pricing models," Econometrica, Vol. 59, No. 2, pp. 371-396.

Uribe, M. (2006) "On Overborrowing," The American Economic Review, pp. 417-421.

Werning, I. and E. Farhi (2012) "Fiscal Unions," NBER Working Paper No. 18280. 


\section{Appendix}

\section{A Numerical solution method}

To solve the model numerically I employ the method proposed by Guerrieri and Lorenzoni (2011).

Computing the steady state of the model involves finding the interest rate that clears the bond market at the world level. The first step consists in deriving the optimal policy functions $C^{T}\left(B, A^{T}\right), C^{N}\left(B, A^{T}\right)$ and $L\left(B, A^{T}\right)$ for a given interest rate $R$. To compute the optimal policy functions I discretize the endogenous state variable $B$ using a uniformly spaced grid with 600 points, and then iterate on the Euler equation and on the intratemporal optimality conditions using the endogenous gridpoints method of Carroll (2006). Using the optimal policies, it is possible to derive the inverse of the bond accumulation policy $g\left(B, A^{T}\right)$. This is used to update the conditional bond distribution $\Psi\left(B, A^{T}\right)$ according to the formula $\Psi_{\tau}\left(B, A^{T}\right)=\sum_{A^{T}} \Psi_{\tau-1}\left(g\left(B, \tilde{A}^{T}\right), \tilde{A}^{T}\right) P\left(A^{T} \mid \tilde{A}^{T}\right)$ for all $B \leq-\kappa$, where $\tau$ is the $\tau$-th iteration and $P\left(A^{T} \mid \tilde{A}^{T}\right)$ is the probability that $A_{t+1}^{T}=A^{T}$ if $A_{t}^{T}=\tilde{A}^{T}$. The bond accumulation function is not invertible at $B=-\kappa$, but the formula above holds if $g\left(-\kappa, A^{T}\right)$ is defined as the largest $B$ such that $B^{\prime}=-\kappa$ is optimal. Once the bond distribution has converged to the stationary distribution, I check whether the market for bonds clears. If not, I update the guess for the interest rate.

To compute the transitional dynamics, I first derive the initial and final steady states. I then choose a $T$ large enough so that the economy has approximately converged to the final steady state at $t=T$ (I use $T=200$, increasing $T$ does not affect the results reported). The next step consists in guessing a path for the interest rate, with $R_{T}=R^{\prime}$. I then set the policy functions for consumption in period $T$ equal to the ones in the final steady state and iterate backward on the Euler equation and on the intratemporal optimality conditions to find the sequence of optimal policies $\left\{\mathrm{C}_{t}^{T}\left(B, A^{T}\right), C_{t}^{N}\left(B, A^{T}\right), L_{t}\left(B, A^{T}\right)\right\}$. Next, I use the optimal policies to compute the sequence of bond distributions $\Psi_{t}\left(B, A^{T}\right)$ going forward from $t=0$ to $t=T$, starting with the distribution in the initial steady state. Finally, I compute the world demand for bonds in every period and update the path for the interest rate until the market clears in every period.

To compute the transitional dynamics with wage rigidities I follow a similar method. The only difference is that the equilibrium in period $t=0$ has to be modified to take into account the presence of pre-set wages. 
Also the numerical solution to the model with multi-period wage rigidities is derived using the method described above. However, the presence of another endogenous state variable, the period 0 nominal wage, for the periods in which wages are partly rigid increases significantly the time needed to obtain a numerical solution.

\section{B A model with interest rate spreads}

In the model presented in the main text all the agents, and countries, are subject to the same interest rate. However, in many cases tight credit conditions manifest themselves with high interest rates. In fact, often countries whose access to the international credit markets is restricted are charged a spread over the interest rate paid by unconstrained countries. This appendix shows how it is possible to reconcile this fact with the model without changing any of the results. In particular, in this appendix I present a model in which the borrowing limit is enforced through interest rate spreads and show that this model is isomorphic to the framework studied in the main text. The discussion draws on Uribe (2006).

For simplicity I focus on the economy without nominal rigidities described in section 2, but the results can be extended to the case of a monetary union with nominal wage rigidities. Suppose that the representative household in country $i$ is charged the country-specific interest rate $R_{i, t}$, potentially different from the world interest rate $R_{t}$. Suppose also that there is no limit to how much the household can borrow at the interest rate $R_{i, t}$. The Euler equation then writes

$$
U_{C_{i, t}^{T}}=R_{i, t} \beta E_{t}\left[U_{C_{i, t+1}^{T}}\right]
$$

In the model in the main text, in which the household is constrained by the borrowing limit (3) and it is charged the world interest rate $R_{t}$, the Euler equation can instead be written as

$$
U_{C_{i, t}^{T}}=\frac{R_{t}}{1-\frac{\mu_{i, t} R_{t}}{U_{C_{i, t}^{T}}}} \beta E_{t}\left[U_{C_{i, t+1}^{T}}\right]
$$

where $\mu_{i, t}$ is the Lagrange multiplier on the borrowing constraint.

Notice that if the household is charged the interest rate

$$
R_{i, t}=\frac{R_{t}}{1-\frac{\mu_{i, t} R_{t}}{U_{C_{i, t}^{T}}}},
$$

the two Euler equations coincide. Moreover, we have that $R_{i, t}=R_{t}$ when $\mu_{i, t}=0$, while 
$R_{i, t}>R_{t}$ when $\mu_{i, t}>0 .{ }^{47}$ Intuitively, investors can make sure that an household respects the borrowing limit by charging a positive spread over the world interest rate anytime the household would violate the constraint if charged the world interest rate. In equilibrium, we would thus observe that high-debt constrained countries are charged a positive spread over the world interest rate.

To obtain a version of the model with interest rate spreads isomorphic to the model in the main text, we must make sure that the resource constraint of the household is not affected by the interest rate spreads. Indeed, whenever the constraint is binding there is a financial rent given by the difference between the cost of funds for the investor and the interest rate that the borrower would like to pay. In the model in the main text this rent accrues to the borrower, since constrained borrowers are charged the world interest rate, that is the cost of funds for investors. We must then ensure that financial rents go fully to the borrower also in the version of the model with interest rate spreads. Following Uribe (2006), this can be done by assuming the existence of domestic financial intermediaries that borrow at the world interest rate $R_{t}$ and lend to households at the interest rate $R_{i, t}$. Assuming that the profits of the domestic financial intermediaries are fully rebated to households in a lump sum fashion, we obtain that the economy with the borrowing constraint described in the main text is isomorphic to the economy with spreads described in this appendix.

\section{Proof of proposition 1}

To prove that from the perspective of a single country the equilibrium with flexible wages attains the first best I characterize the solution to the social planner problem for a single country. Importantly, the social planner in a single country takes the world interest rate as given, since a single country is too small to influence the world interest rate.

The social planner in a generic country $i$ chooses $C_{i, t}^{T}, C_{i, t}^{N}, L_{i, t}, L_{i, t}^{T}, L_{i, t}^{N}$ and $B_{i, t+1}$, taking the path for the interest rate $\left\{R_{t}\right\}_{t=0}^{\infty}$ and the initial bond position $B_{i, 0}$ as given, to maximize expected utility

$$
E_{0}\left[\sum_{t=0}^{\infty} \beta^{t} U\left(C_{i, t}^{T}, C_{i, t}^{N}, L_{i, t}\right)\right],
$$

subject to the resource constraints

$$
C_{i, t}^{T}=A_{i, t}^{T}\left(L_{i, t}^{T}\right)^{\alpha_{T}}+B_{i, t}-\frac{B_{i, t+1}}{R_{t}}
$$

\footnotetext{
${ }^{47}$ Using the fact that $\mu_{i, t} \geq 0$ and rearranging the Euler equation in the main text, it is easy to check that $\mu_{i, t} R_{t} / U_{C_{i, t}^{T}}<1$.
} 


$$
\begin{gathered}
C_{i, t}^{N}=A^{N}\left(L_{i, t}^{N}\right)^{\alpha_{N}} \\
L_{i, t}^{T}+L_{i, t}^{N}=L_{i, t},
\end{gathered}
$$

and the borrowing constraint

$$
B_{i, t+1} \geq-\kappa
$$

The first order conditions are

$$
\begin{gathered}
U_{C_{i, t}^{T}}=\lambda_{i, t}^{T} \\
U_{C_{i, t}^{N}}=\lambda_{i, t}^{N} \\
-U_{L_{i, t}}=\lambda_{i, t}^{L} \\
\lambda_{i, t}^{T} \alpha_{T} A_{i, t}^{T}\left(L_{i, t}^{T}\right)^{\alpha_{T}-1}=\lambda_{i, t}^{L} \\
\lambda_{i, t}^{N} \alpha_{N} A^{N}\left(L_{i, t}^{N}\right)^{\alpha_{N}-1}=\lambda_{i, t}^{L} \\
\frac{U_{C_{i, t}^{T}}^{T}}{R_{t}}=\beta E_{t}\left[U_{C_{i, t+1}^{T}}\right]+\mu_{i, t} \\
B_{i, t+1} \geq-\kappa, \quad \text { with equality if } \mu_{i, t}>0
\end{gathered}
$$

where $U_{x}$ denotes the first derivative of the utility function with respect to $x$ and $\lambda_{i}^{T}, \lambda_{i}^{N}, \lambda_{i}^{L}$ and $\mu_{i}$ are the Lagrange multiplier associated respectively with constraint $(C .1),(C .2),(C .3)$ and (C.4) .

Defining

$$
\begin{array}{r}
w_{i, t}=\frac{\lambda_{i, t}^{L}}{\lambda_{i, t}^{T}} \\
p_{i, t}^{N}=\frac{\lambda_{i, t}^{N}}{\lambda_{i, t}^{T}},
\end{array}
$$

it is easy to verify that the social planner allocation coincide with the equilibrium conditions of the flexible wage version of the model presented in section 2 . 



\section{Index of Working Papers:}

\begin{tabular}{|c|c|c|c|}
\hline $\begin{array}{l}\text { September } 1 \\
2008\end{array}$ & Markus Knell & 146 & $\begin{array}{l}\text { The Optimal Mix Between Funded and } \\
\text { Unfunded Pensions Systems When People } \\
\text { Care About Relative Consumption }\end{array}$ \\
\hline $\begin{array}{l}\text { September 8, } \\
2008\end{array}$ & $\begin{array}{l}\text { Cecilia } \\
\text { García-Peñalosa }\end{array}$ & 147 & $\begin{array}{l}\text { Inequality and growth: Goal conflict or } \\
\text { necessary prerequisite? }\end{array}$ \\
\hline $\begin{array}{l}\text { September 30, } \\
2008\end{array}$ & $\begin{array}{l}\text { Fabio Rumler and } \\
\text { Maria Teresa } \\
\text { Valderrama }\end{array}$ & 148 & $\begin{array}{l}\text { Comparing the New Keynesian Phillips } \\
\text { Curve with Time Series Models to Forecast } \\
\text { Inflation }\end{array}$ \\
\hline $\begin{array}{l}\text { January 30, } \\
2009\end{array}$ & $\begin{array}{l}\text { Claudia Kwapil, } \\
\text { Johann Scharler }\end{array}$ & 149 & $\begin{array}{l}\text { Expected Monetary Policy and the } \\
\text { Dynamics of Bank Lending Rates }\end{array}$ \\
\hline $\begin{array}{l}\text { February 5, } \\
2009\end{array}$ & $\begin{array}{l}\text { Thomas Breuer, } \\
\text { Martin Jandačka, } \\
\text { Klaus Rheinberger, } \\
\text { Martin Summer }\end{array}$ & 150 & $\begin{array}{l}\text { How to find plausible, severe, and useful } \\
\text { stress scenarios }\end{array}$ \\
\hline $\begin{array}{l}\text { February 11, } \\
2009\end{array}$ & $\begin{array}{l}\text { Martin Schneider, } \\
\text { Christian Ragacs }\end{array}$ & 151 & $\begin{array}{l}\text { Why did we fail to predict GDP during the } \\
\text { last cycle? A breakdown of forecast errors } \\
\text { for Austria }\end{array}$ \\
\hline $\begin{array}{l}\text { February 16, } \\
2009\end{array}$ & $\begin{array}{l}\text { Burkhard Raunig, } \\
\text { Martin Scheicher }\end{array}$ & 152 & $\begin{array}{l}\text { Are Banks Different? Evidence from the } \\
\text { CDS Market }\end{array}$ \\
\hline $\begin{array}{l}\text { March 11, } \\
2009\end{array}$ & $\begin{array}{l}\text { Markus Knell, } \\
\text { Alfred Stiglbauer }\end{array}$ & 153 & $\begin{array}{l}\text { The Impact of Reference Norms on Inflation } \\
\text { Persistence When Wages are Staggered }\end{array}$ \\
\hline May 14,2009 & Tarek A. Hassan & 154 & $\begin{array}{l}\text { Country Size, Currency Unions, and } \\
\text { International Asset Returns }\end{array}$ \\
\hline May 14, 2009 & Anton Korinek & 155 & $\begin{array}{l}\text { Systemic Risk: Amplification Effects, } \\
\text { Externalities, and Policy Responses }\end{array}$ \\
\hline May 29, 2009 & Helmut Elsinger & 156 & $\begin{array}{l}\text { Financial Networks, Cross Holdings, and } \\
\text { Limited Liability }\end{array}$ \\
\hline July 20, 2009 & Simona Delle Chiaie & 157 & $\begin{array}{l}\text { The sensitivity of DSGE models' results to } \\
\text { data detrending }\end{array}$ \\
\hline $\begin{array}{l}\text { November 10, } \\
2009\end{array}$ & $\begin{array}{l}\text { Markus Knell } \\
\text { Helmut Stix }\end{array}$ & 158 & $\begin{array}{l}\text { Trust in Banks? } \\
\text { Evidence from normal times } \\
\text { and from times of crises }\end{array}$ \\
\hline
\end{tabular}




\begin{tabular}{ll}
\hline November 27, & Thomas Scheiber \\
2009 & Helmut Stix
\end{tabular}

159 Euroization in Central, Eastern and Southeastern Europe - New Evidence On Its Extent and Some Evidence On Its Causes

160 Spatial Filtering, Model Uncertainty and the Speed of Income Convergence in Europe

\begin{tabular}{llrl}
\hline January 11, & Jesús Crespo & 160 & Spatial Filtering, Model Uncertainty and th \\
2010 & Cuaresma & Speed of Income Convergence in Europe \\
& Martin Feldircher & & \\
&
\end{tabular}

March 29, Markus Knell 2010

\begin{tabular}{ll}
\hline May 31, 2010 & $\begin{array}{l}\text { Zeno Enders } \\
\text { Philip Jung } \\
\text { Gernot J. Müller }\end{array}$ \\
\hline $\begin{array}{l}\text { August 25, } \\
2010\end{array}$ & $\begin{array}{l}\text { Marianna Červená } \\
\text { Martin Schneider }\end{array}$
\end{tabular}

September 8, Sylvia Kaufmann

$2010 \quad$ Johann Scharler

161 Nominal and Real Wage Rigidities. In Theory and in Europe

162 Has the Euro changed the Business Cycle?

163 Short-term forecasting GDP with a DSGE model augmented by monthly indicators

164 Bank-Lending Standards, the Cost Channel and Inflation Dynamics

165 Independence Tests based on Symbolic Dynamics

166 Firms' Reactions to the Crisis and their Consequences for the Labour Market. Results of a Company Survey conducted in Austria

\begin{tabular}{llrl}
\hline May 10, 2011 & Helmut Stix & 167 & $\begin{array}{l}\text { Does the Broad Public Want to Consolidate } \\
\text { Public Debt? - The Role of Fairness and of } \\
\text { Policy Credibility }\end{array}$ \\
\hline May 11, 2011 & $\begin{array}{l}\text { Burkhard Raunig, } \\
\text { Johann Scharler }\end{array}$ & 168 & $\begin{array}{l}\text { Stock Market Volatility, Consumption and } \\
\text { Investment; An Evaluation of the Uncertainty } \\
\text { Hypothesis Using Post-War U.S. Data }\end{array}$ \\
\hline May 23, 2011 & Steffen Osterloh & 169 & $\begin{array}{l}\text { Can Regional Transfers Buy Public } \\
\text { Support? Evidence from EU Structural } \\
\text { Policy }\end{array}$ \\
& & $170 \begin{array}{l}\text { Bank Bailouts, International Linkages and } \\
\text { Cooperation }\end{array}$ \\
\hline May 23, 2011 & $\begin{array}{l}\text { Friederike Niepmann } \\
\text { Tim Schmidt-Eisenlohr }\end{array}$ & 171 & $\begin{array}{l}\text { Households' Foreign Currency Borrowing in } \\
\text { Central and Eastern Europe }\end{array}$ \\
\hline $\begin{array}{l}\text { September 1, } \\
2011\end{array}$ & $\begin{array}{l}\text { Jarko Fidrmuc, } \\
\text { Mariya Hake, } \\
\text { Helmut Stix }\end{array}$ & \\
\hline
\end{tabular}




\begin{tabular}{|c|c|c|c|}
\hline $\begin{array}{l}\text { September 9, } \\
2011\end{array}$ & $\begin{array}{l}\text { Jürgen Eichberger, } \\
\text { Klaus Rheinberger, } \\
\text { Martin Summer }\end{array}$ & 172 & Credit Risk in General Equilibrium \\
\hline $\begin{array}{l}\text { October 6, } \\
2011\end{array}$ & Peter Lindner & 173 & $\begin{array}{l}\text { Decomposition of Wealth and Income using } \\
\text { Micro Data from Austria }\end{array}$ \\
\hline $\begin{array}{l}\text { October 18, } \\
2011\end{array}$ & Stefan Kerbl & 174 & $\begin{array}{l}\text { Regulatory Medicine Against Financial } \\
\text { Market Instability: } \\
\text { What Helps And What Hurts? }\end{array}$ \\
\hline $\begin{array}{l}\text { December 31, } \\
2011\end{array}$ & $\begin{array}{l}\text { Konstantins Benkovskis } \\
\text { Julia Wörz }\end{array}$ & 175 & How Does Quality Impact on Import Prices? \\
\hline $\begin{array}{l}\text { January } 17, \\
2012\end{array}$ & Nicolás Albacete & 176 & $\begin{array}{l}\text { Multiple Imputation in the Austrian } \\
\text { Household Survey on Housing Wealth }\end{array}$ \\
\hline $\begin{array}{l}\text { January 27, } \\
2012\end{array}$ & $\begin{array}{l}\text { Gerhard Fenz, } \\
\text { Lukas Reiss, } \\
\text { Martin Schneider }\end{array}$ & 177 & $\begin{array}{l}\text { A structural interpretation of the impact of } \\
\text { the great recession on the Austrian } \\
\text { economy using an estimated DSGE model }\end{array}$ \\
\hline $\begin{array}{l}\text { July } 27 \\
2012\end{array}$ & Helmut Stix & 178 & $\begin{array}{l}\text { Why Do People Save in Cash? Distrust, } \\
\text { Memories of Banking Crises, Weak } \\
\text { Institutions and Dollarization }\end{array}$ \\
\hline $\begin{array}{l}\text { August 20, } \\
2012\end{array}$ & Markus Knell & 179 & $\begin{array}{l}\text { Increasing Life Expectancy and Pay-As- } \\
\text { You-Go Pension Systems }\end{array}$ \\
\hline $\begin{array}{l}\text { September 25, } \\
2012\end{array}$ & $\begin{array}{l}\text { Fabio Rumler, } \\
\text { Walter Waschiczek }\end{array}$ & 180 & $\begin{array}{l}\text { Have Changes in the Financial Structure } \\
\text { Affected Bank Protability? Evidence for } \\
\text { Austria }\end{array}$ \\
\hline $\begin{array}{l}\text { November 9, } \\
2012\end{array}$ & $\begin{array}{l}\text { Elisabeth Beckmann, } \\
\text { Jarko Fidrmuc, } \\
\text { Helmut Stix }\end{array}$ & 181 & $\begin{array}{l}\text { Foreign Currency Loans and Loan Arrears } \\
\text { of Households in Central and Eastern } \\
\text { Europe }\end{array}$ \\
\hline $\begin{array}{l}\text { June 10, } \\
2013\end{array}$ & Luca Fornaro & 182 & International Debt Deleveraging \\
\hline
\end{tabular}





\section{Call for Applications: \\ Visiting Research Program}

The Oesterreichische Nationalbank (OeNB) invites applications from external researchers for participation in a Visiting Research Program established by the OeNB's Economic Analysis and Research Department. The purpose of this program is to enhance cooperation with members of academic and research institutions (preferably post-doc) who work in the fields of macroeconomics, international economics or financial economics and/or with a regional focus on Central, Eastern and Southeastern Europe.

The OeNB offers a stimulating and professional research environment in close proximity to the policymaking process. Visiting researchers are expected to collaborate with the OeNB's research staff on a prespecified topic and to participate actively in the department's internal seminars and other research activities. They will be provided with accommodation on demand and will, as a rule, have access to the department's computer resources. Their research output may be published in one of the department's publication outlets or as an OeNB Working Paper. Research visits should ideally last between 3 and 6 months, but timing is flexible.

Applications (in English) should include

- a curriculum vitae,

- a research proposal that motivates and clearly describes the envisaged research project,

- an indication of the period envisaged for the research visit, and

- information on previous scientific work.

Applications for 2014 should be e-mailed to eva.gehringer-wasserbauer@oenb.at by November 1, 2013.

Applicants will be notified of the jury's decision by mid-December. The following round of applications will close on May 1, 2014. 